\title{
Formation and geochronology of Last Interglacial to Lower Weichselian loess/palaeosol sequences - case studies from the Lower Rhine Embayment, Germany
}

\author{
Peter Fischer, Alexandra Hilgers, Jens Protze, Holger Kels, Frank Lehmkuhl, Renate Gerlach
}

How to cite: $\quad$ Fischer, P.; Hilgers, A.; Protze, J.; Kels, H.; Lehmkuhl, F.; Gerlach, R. (2012): Formation and geochronology of Last Interglacial to Lower Weichselian loess/palaeosol sequences - case studies from the Lower Rhine Embayment, Germany. - E\&G Quaternary Science Journal, 61 (1): 48-63. DOI: 10.3285/eg.61.1.04

Abstract:

\begin{abstract}
Located in the Lower Rhine area two loess/palaeosol sections were investigated focusing on the last Interglacial to Lower Weichselian pedosedimentary sequence. The sections are situated in the brown coal opencast mining area of Inden and Garzweiler, and comprise archaeological find layers from the Middle Palaeolithic. Selected ratios derived from multi-element analysis are presented for the first time for the prominent loess accumulation area north of the Rhenish Shield. In addition luminescence ages were determined based on isothermal thermoluminescence (ITL) and optically stimulated luminescence (OSL) using the quartz mineral fraction. The results indicate multiple sediment redeposition and polygenetic soil formation for both sections displaying a complex formation of the investigated sequences. Due to the polygenetic character of the loess/palaeosol sequences, interpretation in terms of stratigraphical correlation and palaeoclimatic reconstruction is not straightforward. In addition, the geomorphological position and the formation of the palaeorelief in the surrounding area of loess/palaeosol sequences have to be taken into account as important factors of the geomorphodynamic and soil forming processes of the past.
\end{abstract}

Genese und Chronologie von letztinterglazialen bis früh-weichselzeitlichen Löss-Paläoboden-Abfolgen - Beispiele aus der Niederrheinischen Bucht, Deutschland

Kurzfassung:

Anhand zweier Profile aus dem Niederrheingebiet wird die Komplexität der Genese und Chronologie letztinterglazialer bis früh-weichselzeitlicher Löss-Paläoboden-Sequenzen diskutiert. Die untersuchten Profile wurden in den Braunkohletagebauen Inden und Garzweiler aufgenommen und sind mit mittelpaläolithischen Fundkomplexen verknüpft. Erstmalig werden dabei Multi-Element-Analysen neben Lumineszenz-Datierungen an Quarzen (ITL, OSL) aus niederrheinischen Lössprofilen vorgestellt und diskutiert. Die Ergebnisse offenbaren große Unsicherheiten hinsichtlich einer stratigraphischen und paläoklimatischen Interpretation von polygenetisch überprägten Sediment- und Paläobodensequenzen. Eine bedeutende Rolle nimmt dabei auch die Reliefposition in Verbindung mit der Morphogenese des Paläoreliefs ein, die in höherem Maße als bisher berücksichtigt werden sollte.

Keywords: Loess stratigraphy, Lower Rhine area, pedocomplexes, multi element analysis, luminescence chronology, Last Interglacial, Lower Weichselian

Addresses of authors: P. Fischer, A. Hilgers, Institute for Geography, University of Cologne, Albertus-Magnus-Platz, 50923 Cologne, Germany, E-Mail: peter.fischer@uni-koeln.de; F. Lehmkuhl, H. Kels, J. Protze, Chair of Physical Geography and Geoecology, Department of Geography, RWTH Aachen University, Wüllnerstr. 5b, 52062 Aachen, Germany; R. Gerlach, Landschaftsverband Rheinland, Amt für Bodendenkmalpflege im Rheinland, Endenicher Str. 133, 53115 Bonn, Germany.

\section{Introduction}

This study is concerned with loess sediments and pedocomplexes from the Lower Rhine Embayment, which is a prominent loess accumulation area north of the Rhenish Shield in western Central Europe. The loess research in Central Europe and in Germany has a long tradition (cf. PÉcSI \& Richter 1996; Smalley et al. 2001; Zöller \& Semmel 2001).

For the Lower Rhine area, detailed discussions of the early stages of loess research were presented by Henze (1998), KELS (2007) and Fischer (2010). Especially the improvement of palaeopedological methods in the second half of the last century enabled the development of a general stratigraphical scheme for the Upper Pleistocene (e.g. SchönhALs et al. 1964; Rohdenburg \& Meyer 1966; Semmel 1968). Essential chronostratigraphical studies from the Lower Rhine area (e.g. Remy 1960; PAAs 1968a, b; BrunNACKer 1967) were based on the stratigraphical relation to underlying fluvial terraces and counting of palaeosols from top to bottom. This approach did not consider erosional unconformities and hiatuses within the studied sequences (cf. SCHIRMER 2003). In the last two decades a comprehensive loess stratigraphy for the Lower Rhine area has been developed by SCHIRMER (e.g. 1999, 2000a, 2000b, 2002, 2010).

In their function as archives of climate and environmental change during the Middle and Upper Pleistocene loess/ palaeosol sequences are being investigated in recent times using a wide methodological spectrum, including sedimentological, geochemical, palaeopedological and geochronological approaches. Geochemical weathering indices derived from multi-element analyses have recently been applied as promising tool for the palaeoclimatical interpretation of Pleistocene as well as Holocene pedosedimentary records (e.g. LIU, 1985, 1991; DerbyshiRE et al. 1995; 


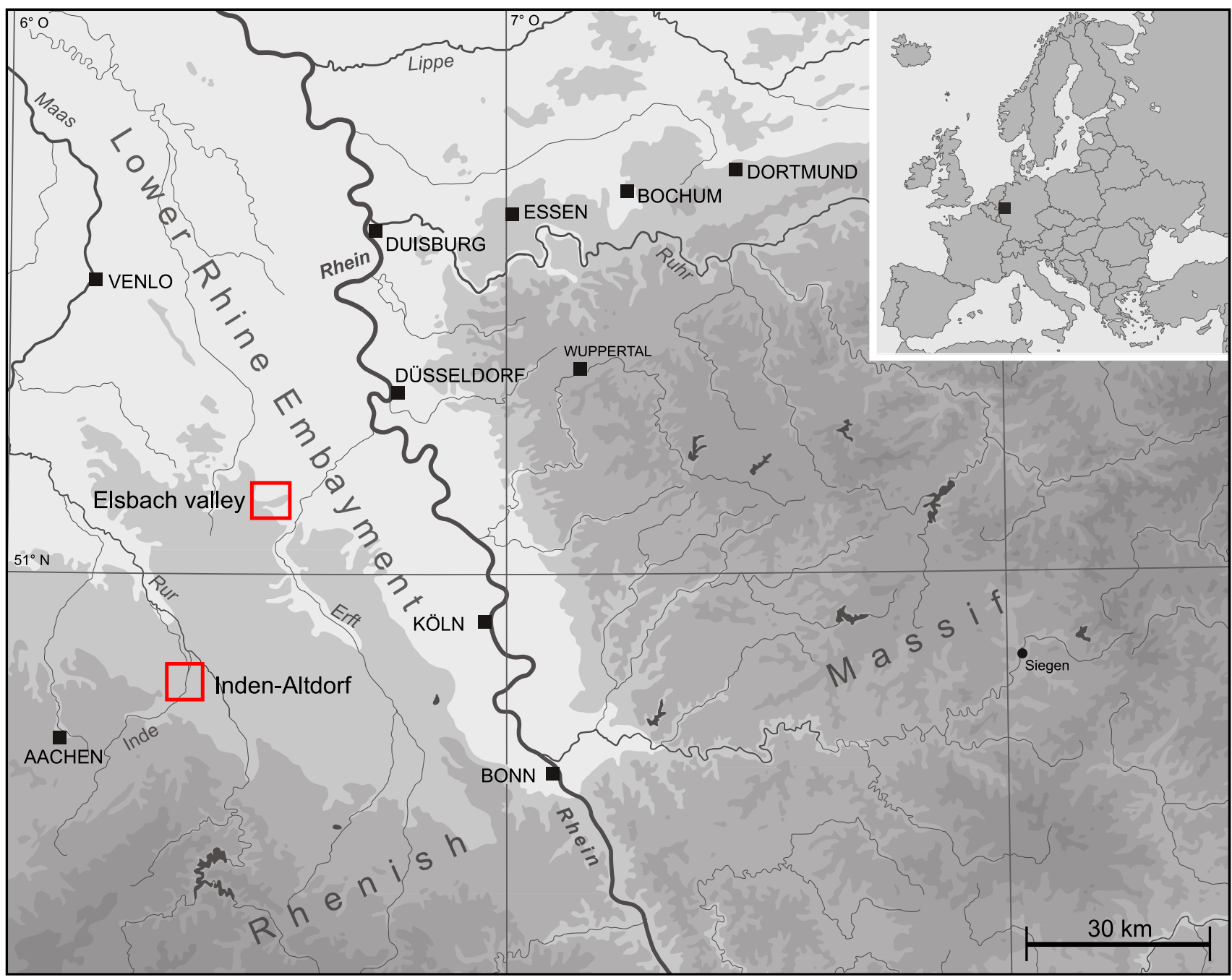

Fig. 1: Map showing the location of study sites in the Lower Rhine Embayment.

Abb. 1: Lage der Untersuchungsgebiete in der Niederrheinischen Bucht.

Gallet et al. 1996; BoKhorst et al. 2008; Buggle et al. 2008; BugGLE et al. 2010). Furthermore, geochemical fingerprints can give important clues on lithological changes reflecting soil and geomorphodynamic processes during the formation of loess deposits. However, for the Rhenish loess area comparably few geochemical studies are available (SMYkatz-Kloss 2003; Smykatz-Kloss et al. 2004).

Loess deposits were among the first sediments being systematically dated with luminescence techniques (Preusser et al. 2008) enabling the direct determination of their time of deposition. Overviews of the state of the art in luminescence dating on Pleistocene loess sediments are given in Singhvi et al. (2001), Koster (2005), Roberts (2008) and Preusser et al. (2008). Published luminescence data obtained for loess deposits of the Lower Rhine area are mainly based on thermoluminescence (TL) and infra-red stimulated luminescence of feldspars (IRSL) and concentrate on a few type localities (ZöLLER et al. 1988; Zöller 1989; JanotTA 1991; Frechen et al. 1992; BoenigK \& Frechen 1995). Thus, there is still a need for systematic dating of loess deposits applying different luminescence dating approaches.

The present study focuses upon the sedimentological and geochemical characteristics as well as the chronology of pedocomplexes of Eemian and Lower Weichselian age in the Lower Rhine area. For two sites, a robust chronological frame shall be established, and the use of multi-element analyses will be tested and discussed. As the records under investigation are related to archaeological finds correlating to the Middle Palaeolithic, the results contribute to a better understanding of site formation processes (e.g. UTHMEIER 2006).

\section{Regional setting and investigated loess sections}

\subsection{The loess/palaeosol sequence of the Elsbach valley [Garzweiler]}

The investigated section of the Elsbach valley (archaeological documentation number FR 2006/0086, feature 5) is situated in the north-eastern Jülicher Börde, close to the brown coal opencast mining area Garzweiler (Fig. 1, 2). In this area the loess covered Upper Terrace of the River Rhine is dissected by numerous dry valleys. The section is located on the middle slope of the Elsbach valley facing to the south. The importance of (palaeo-) depressions for the conservation of stretched stratigraphical records in this area is well known and loess/palaeosol sequences from the 


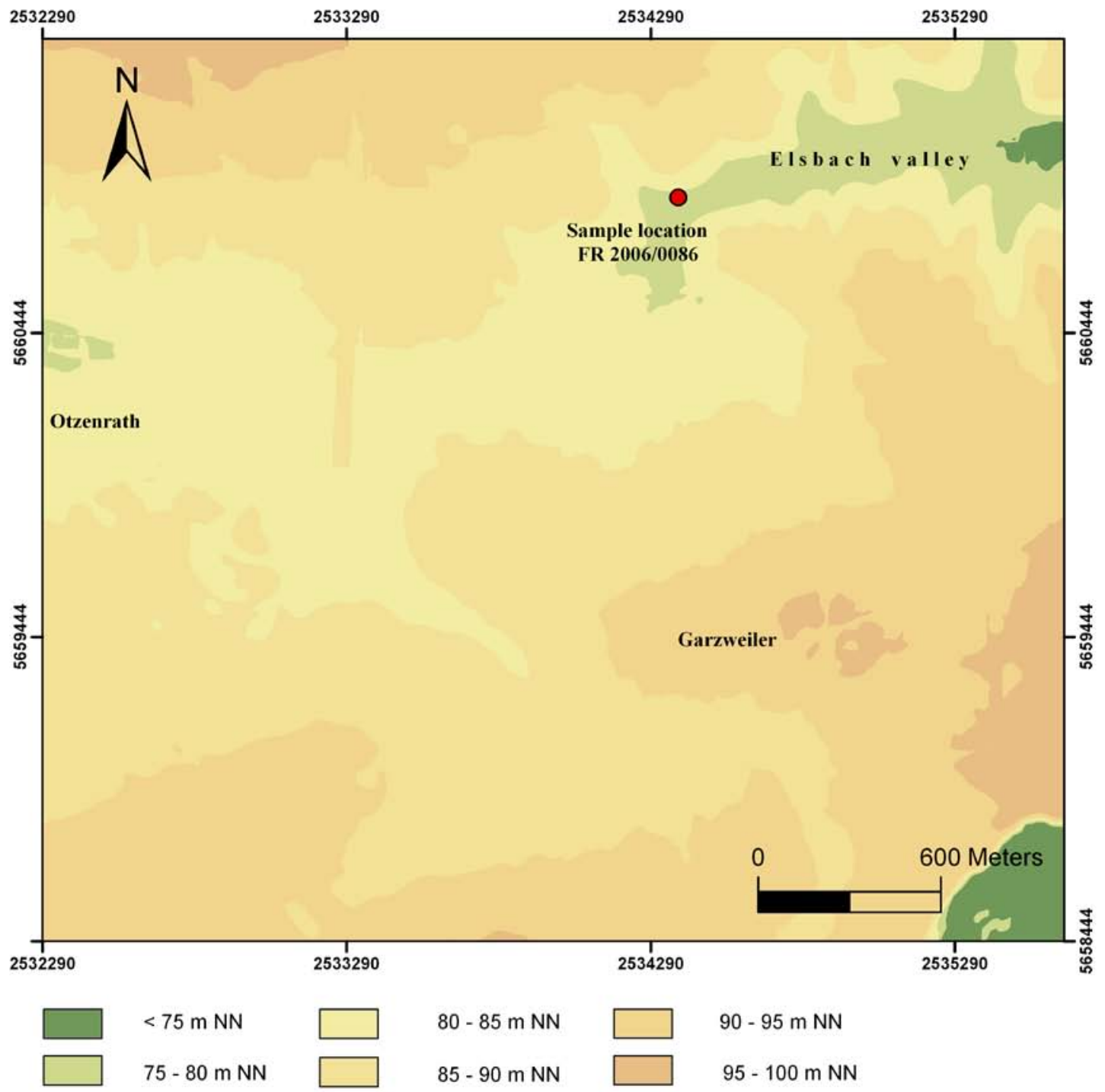

Fig. 2: Position of the loess/palaeosol record in the Elsbach valley (Garzweiler). The map shows the former morphology (prior to further mining) based on the digital elevation model (Data source: Geobasisdaten, Landesvermessungsamt NRW (2008), DEM 5, courtesy of the Rhineland Regional Council, LVR).

Abb. 2: Lage des Lössprofils im Elsbachtal. Die Karte zeigt die morphologische Situation (vor dem mittlerweile fortgeschrittenen Abbau) auf Basis des DGM 5 (Datenquelle: Geobasisdaten, Landesvermessungsamt NRW 2008, mit Genehmigung des LVR).

Garzweiler area are discussed in numerous publications (e.g. Henze 1998; Kels 2007; Schirmer 2000b, Schirmer 2010; SCHIRMER \& Kels 2002).

The section has a vertical extension of $2.7 \mathrm{~m}$ (Fig. 3). At its base a lamellic Bw horizon occurs, superimposed by clay illuviation from the overlying Btg horizon, which shows concretions of iron and manganese hydroxides. As based on field observations these horizons most likely correlate with a truncated Eemian soil (MIS 5e). The Btg horizon is overlain by a slightly humic Bt and a bleached stagnic horizon. The latter two are separated by an unconformity indicated by occasional gravel. The question arises, if the weak humic Bt horizon represents a soil sediment postdating the "Eemian" soil. The bleached stagnic horizon is overlain by a slightly humous, water stained AhE horizon, which shows weak Bt-features and decomposition of organic material. The following humic layers can be separated into a lower, rust spotted, clay-rich horizon and an upper horizon characterised by increasing organic carbon content and enrichment of secondary carbonate.
Small cryogenic cracks intrude from the overlying soil sediment into the Ah horizon.

The uppermost part is considerably reworked as characterised by tongue-like soil material imbedded within calcareous loess sediments.

\subsection{The loess/palaeosol record of Inden-Altdorf}

The site of Inden-Altdorf is situated in the south-eastern part of the Aldenhovener Platte, which is part of the southern loess landscape of the Jülicher Börde. Here, the loessbelt, continuing westwards to the Zülpicher Börde, is interrupted by the River Inde, a tributary to the River Rur, both having their sources in the Rhenish Massif (Fig. 1). The Aldenhovener Platte slopes downward in northerly and north-easterly direction. Several tectonic dislocations occur, striking from northwest to southeast (cp. AHORNER 1962).

On average the loess cover reaches thicknesses between 3 and 7 metres, growing up to 11 metres in local palaeo- 


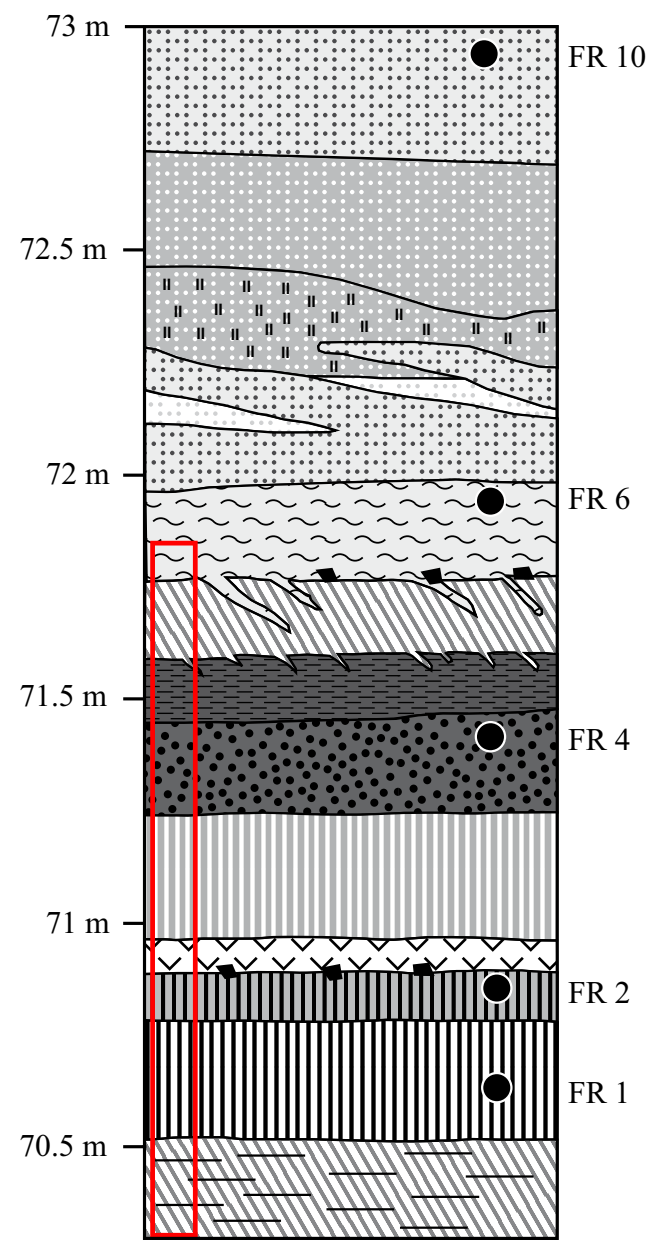

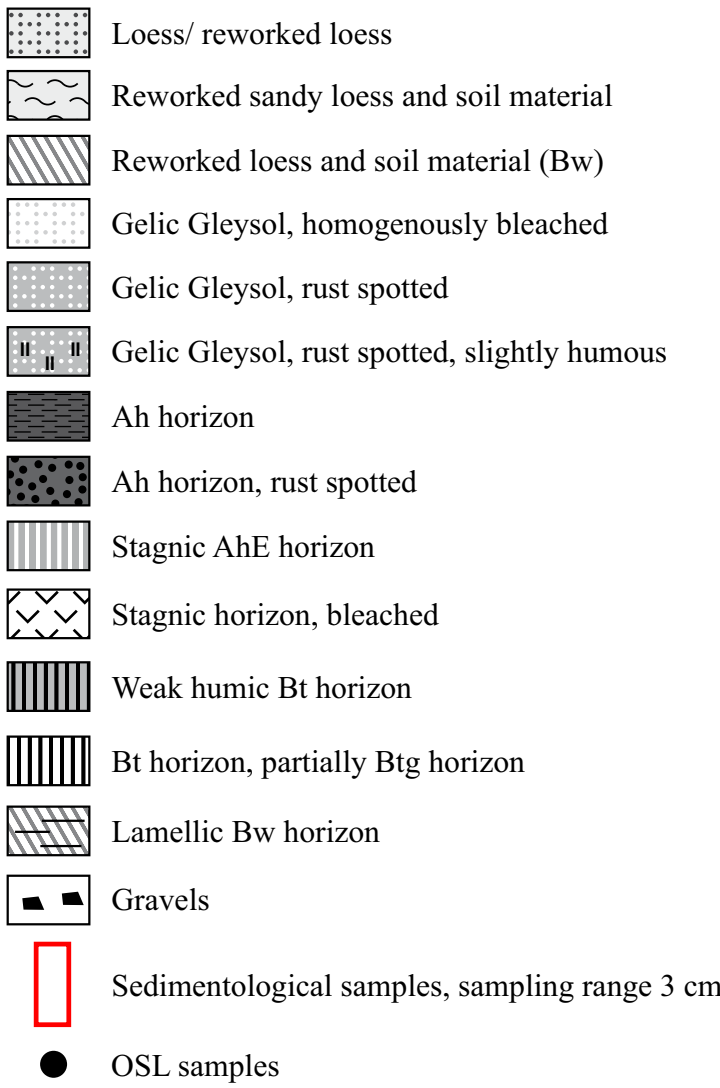

Fig. 3: Litho- and pedological composition of the loess/palaeosol record of Garzweiler/Elsbach valley (FR 2006/0086, feature 5; Position (German Grid) R: 2534381, H: 5660889, 75 m a.s.l.).

Abb. 3: Litho- und pedologischer Aufbau der Loess-Paläoboden-Sequenz aus Garzweiler/Elsbachtal (FR 2006/0086, Stelle 5; Lage (Gauß-Grüger Koordinaten) $R: 2534381, H: 5660889,75 m \ddot{u} . N N)$.

channels (Kels 2007; PAAs 1968a, b). These palaeochannels are often connected to tectonic subsidence and represent positions of major relevance for conservation of older loess sediments and pedocomplexes in the Lower Rhine area. The loess sediments cover Early- and Mid-Pleistocene fluvial deposits of the rivers Rhine and Meuse and their tributaries. From this area only few loess sections were investigated (PAAs 1961, 1968a, b; LÖHR \& BRUNNACKER 1974; HENZE 1998).

The documentation and sampling of the loess/palaeosol record of Inden-Altdorf as described in the following was conducted during an archaeological excavation (WW 2005/91) in the forefront of the brown coal mining area Inden (Fig. 4, 5). The archaeological finds were dated to the Middle Palaeolithic (Thissen 2006, 2007; Kels et al. 2009; Pawlik \& Thissen 2011).

Attuned to the River Inde in its function as local erosional base numerous dry valleys exist dissecting the loess landscape. These dry valleys formed under periglacial conditions during the Pleistocene and were affected by colluviation processes during the Holocene caused by human impact on the natural landscape. Taking these processes into account a considerably more accentuated relief can be presumed for the time before major soil erosion (cf. ScHulz 2007).

The investigated record with a vertical extension of $2.3 \mathrm{~m}$ is located on the north-eastern inclined shoulder of the south-eastern slope of the Altdorf dell (Fig. 4). The base comprises a Bt horizon characterised by a reddish brown colour and lamellic clay illuviation, which is overlain by a reddish brown, clay rich Btg horizon. Both horizons show strong hydromorphic staining by iron and manganese hydroxides. Based on the field evidence these horizons most likely correlate with the truncated soil of the Eemian interglacial (MIS 5e). On top of the Btg horizon a stagnic horizon is developed characterised by a light grey colour due to bleaching processes. Within this layer numerous charcoal fragments were found and Middle Palaeolithic finds were imbedded in the surrounding of the sample location. Disturbed soil structure and rounded charcoal fragments indicate reworking processes, further supported by a main artefact concentration at the foot of the slope. The stagnic horizon is overlain by a weak Bt horizon which is slightly humous in the lower part. On top of the Bt horizon a stagnic AhE horizon comprising rounded charcoal was documented. The hanging layer is characterised by reworked soil material, with increasing organic carbon content towards the top and intercalated lamellic silt indicating sheet wash processes. The organic carbon is most likely eluviated from the overlying Ah horizon. A weakly humic Bt with an angular blocky soil structure and clay coatings is superimposing the Ah horizon. This horizon is again overlain by a light brown soil sediment. This reworked soil material 


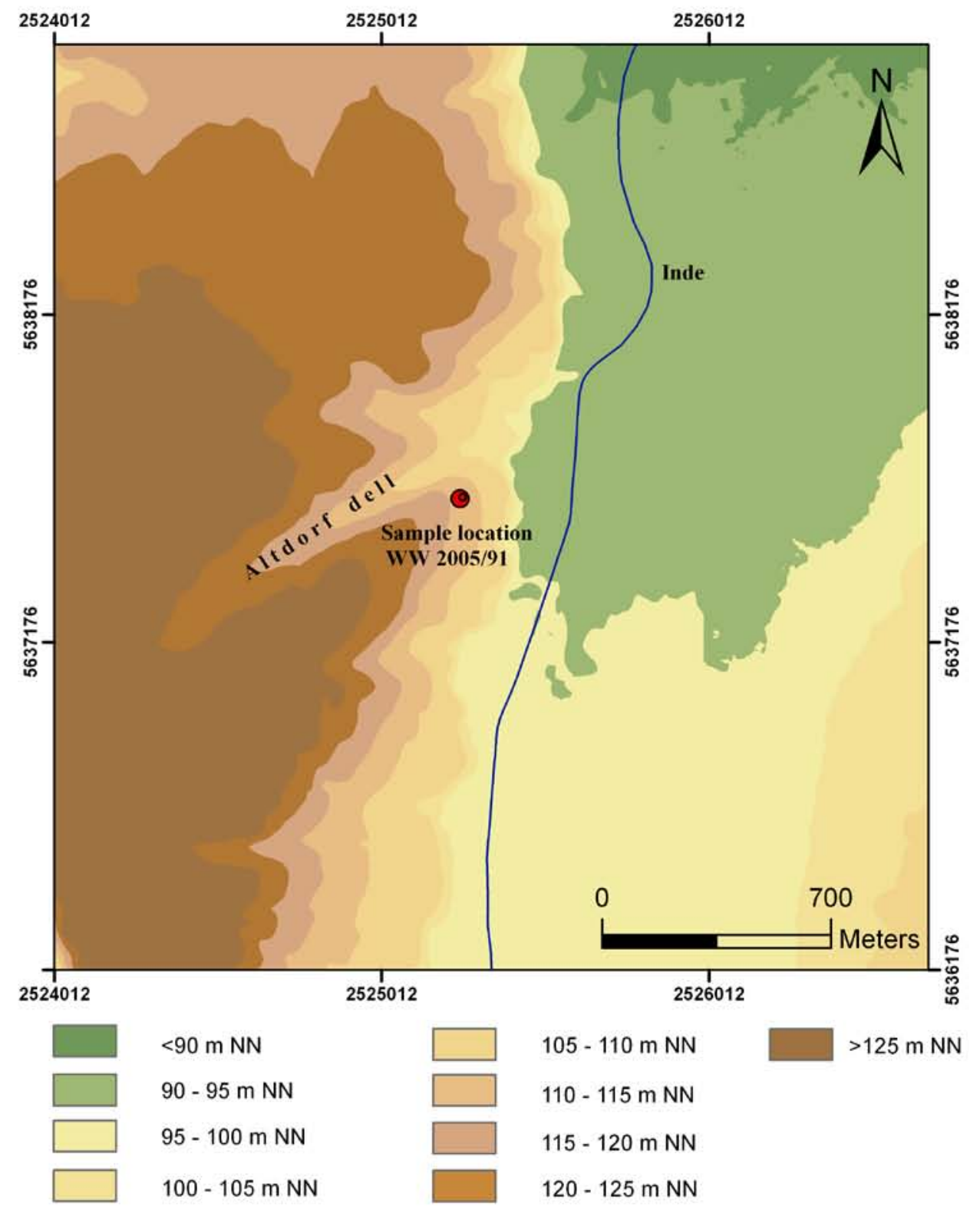

Fig. 4: Position of the loess/palaeosol record of Inden-Altdorf. Map showing the morphology (prior to further mining) based on the digital elevation model (Data source: Geobasisdaten, Landesvermessungsamt NRW (2008), DEM 5, courtesy of the Rhineland Regional Council, LVR).

Abb. 4: Lage des Lössprofils aus Inden-Altdorf. Die Karte zeigt die morphologische Situation (vor dem mittlerweile fortgeschrittenen Abbau) auf Basis des DGM 5 (Datenquelle: Geobasisdaten, Landesvermessungsamt NRW 2008, mit Genehmigung des LVR).

as well as the $\mathrm{Bt}$, Ah and $\mathrm{AhE}$ horizons show secondary carbonate enrichment. The hanging sequence is characterized by yellowish loess sediments showing increasing carbonate content and intercalated Gelic Gleysols, which most likely correlate with the Upper Weichselian (MIS 2). Cryoturbation features with tongue-like structures intrude into the loess sediments.

Both records exhibit signs of strong reworking processes and a reduction of the stratigraphy due to superimposition of different soil formation phases.

Evidence of younger (and weaker) Bt horizons postdating the last interglacial soil is reported by ScHIRMER (e.g. 2002, 2010) for the Lower Rhine area as well as for other loess regions from Germany (e.g. Frechen, BoENIGK o Weidenfeller 1995; Frechen, Terhorst \& RÄhle 2007).

\section{Methods}

\subsection{Sedimentological and geochemical analysis}

In order to obtain high-resolution records, sediment samples were taken at $3 \mathrm{~cm}$ intervals at the lower part of the Elsbach valley sequence and at $5 \mathrm{~cm}$ intervals at the IndenAltdorf sequence (cp. Figs. 3, 5). The grain size distribution of the Inden-Altdorf sequence was determined using a Sedigraph (Micromeritics 5100) measuring the fraction from $63-0.63 \mu \mathrm{m}$. The bulk sample was boiled with $\mathrm{H}_{2} \mathrm{O}_{2}$, resulting in the oxidation of organic matter. Carbonates were dissolved by $\mathrm{HCl}(10 \%)$. Sediment samples were reduced to the fraction $<63 \mu \mathrm{m}$ by sieving and $4 \mathrm{~g}$ per sample were dispersed in $80 \mathrm{ml}$ sodium-pyrophosphate $\left(\mathrm{Na}_{4} \mathrm{P}_{2} \mathrm{O}_{7} \times 10 \mathrm{H}_{2} \mathrm{O}\right)$. 


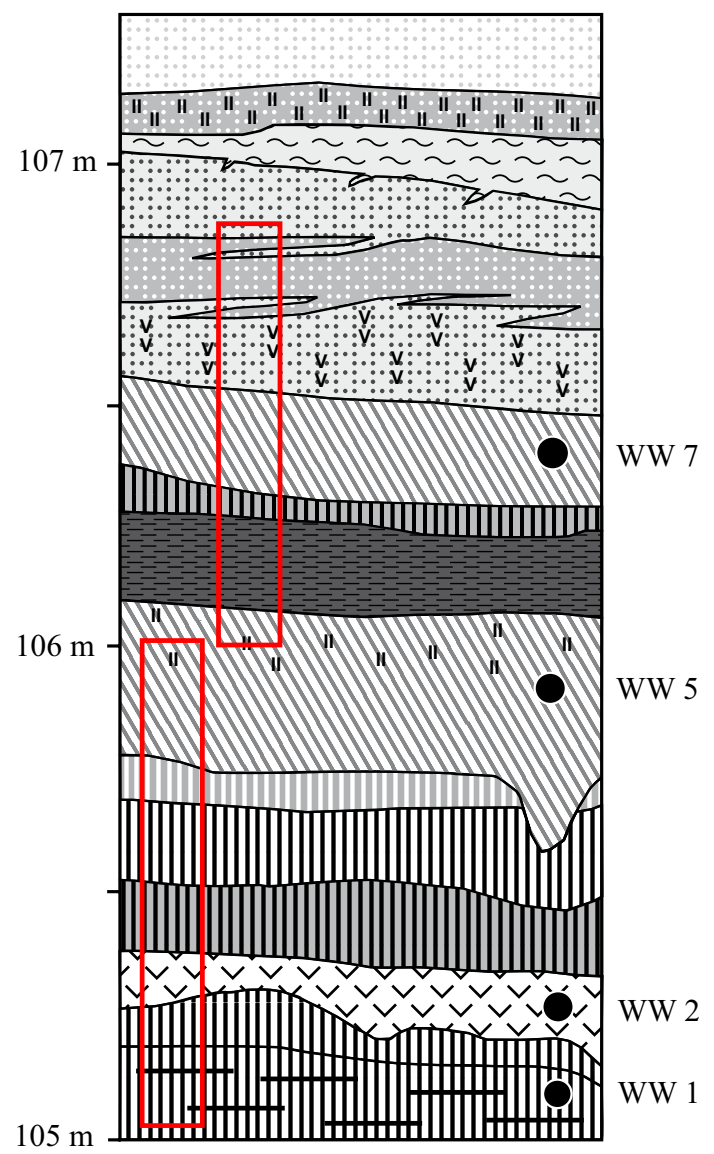

Loess/ reworked loess

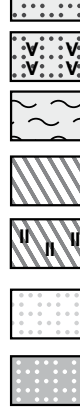

Loess/ reworked loess, hydromorphic stained

Reworked sandy loess and soil material

Reworked loess and soil material (Bw)

Reworked Ah/Bw horizon

Gelic Gleysol, homogenously bleached

Gelic Gleysol, rust spotted

11. iI. Gelic Gleysol, rust spotted, slightly humous

$==2$ Ah horizon

WI Stagnic AhE horizon

드 Stagnic horizon, bleached

||[||]|| Weak humic Bt horizon

||[||]|| Bt horizon, partially Btg horizon

冊冊 Lamellic Bt horizon

Sedimentological samples, sampling range $5 \mathrm{~cm}$

OSL samples

Fig. 5: Litho- and pedological composition of the loess-palaeosol record of Inden-Altdorf (WW 2005/91, feature 125; Position (German Grid) R: 2525252, H: 5637614, 107 m a.s.l.).

Abb. 5: Litho- und pedologischer Aufbau der Löss-Paläoboden Sequenz aus Inden-Altdorf (WW 2005/91, Stelle 125, Lage (Gauß-Krüger Koordinaten) R: 2525252; H: 5637614; $107 \mathrm{~m}$ ü. NN).

In loess/palaeosol sequences initial weathering processes result in dissolution of minerals followed by hydration and hydrolysis. The latter produces new ions and/or insoluble components due to the reaction of minerals with water in more humid periods, in contrast to cold (periglacial) arid periods with loess accumulation. In order to characterise palaeosols in loess sections ratios of soluble cations (e.g. $\mathrm{Na}, \mathrm{K}, \mathrm{Rb}, \mathrm{Mg}, \mathrm{Sr}$ ) to relatively insoluble hydrolysates (e.g. $\mathrm{Al}_{2} \mathrm{O}_{3}, \mathrm{TiO}_{2}$ ) can be determined, in which the weathering processes (as basic soil formation processes) are indicated by decreasing ratios (cp. SMYKATZ-KLOss et al. 2004). In general, with rising radius the mobility of ions decreases and the tendency to be adsorbed to fine grained sediments or soil particles increases (SMYKATZ-KLOss et al. 2004). Thus, large cations like $\mathrm{K}$ and $\mathrm{Rb}$ are increasingly adsorbed whereas for example $\mathrm{Na}$ and $\mathrm{Mg}$ are preferentially leached. Due to intensive weathering and soil formation processes in the more humid climate of Western Central Europe as displayed in the sections under study ratios based on volatile elements such as $\mathrm{Na}$ and $\mathrm{Mg}$ are not as suitable as in loess/palaeosol sequences of more continental climate regions (cp. BoKHORST et al. 2009; BUGGLE et al. 2010; Kabata-Pendias 2010; Hooda, 2010).

For the present study, element contents of calcium $(\mathrm{Ca})$, strontium $(\mathrm{Sr})$, potassium $(\mathrm{K})$, rubidium $(\mathrm{Rb})$ and titanium (Ti) and correlating ratios are included (cp. Figs. 8, 9, $10,11)$.
The $\mathrm{K} / \mathrm{Rb}$ ratio usually decreases during in situ soil formation processes and thus indicates the weathering degree. In loess/palaeosol sequences it is suggested that increasing values in this ratio also reflect secondary potassium enrichment, interpreted as accumulation of clay due to input of pre-weathered material. The $\mathrm{Ti} / \mathrm{Ca}$ ratio indicates increasing weathering degrees by increasing values and is suggested as a primary weathering index. In combination with the K/Ti ratio it allows for a detection of secondary carbonate. Secondary clay enrichment as displayed in high values of the $\mathrm{K} / \mathrm{Rb}$ ratio is attended by high Ti contents. The $\mathrm{Sr} / \mathrm{Rb}$ ratio indicates secondary carbonate precipitation due to a strong affinity of Sr to $\mathrm{Ca}$ as well as clay accumulation due to the high capacity of clay minerals to adsorb $\mathrm{Sr}$ (KABATAPENDIAS 2010). In general crosschecks between selected ratios allow for assuring the deduced interpretation.

The elements were measured using a portable X-ray fluorescence (XRF) device (Niton Xlt 700 Series). The bulk sediment samples were reduced to the fraction $<63 \mu \mathrm{m}$ and prepared for the analytical cuvette. Measurements were obtained in the pre-calibrated bulk mode $(38 \mathrm{KeV}, 10 \mathrm{~W})$.

\subsection{Luminescence dating}

Luminescence dating was carried out at the luminescence dating laboratory of the Institute for Geography, University of Cologne. Here, luminescence ages of nine sediment sam- 
Tab. 1: Dose rate data for the quartz fraction calculated assuming average water contents of $14 \pm 5$ weight-\%. Radionuclide concentrations of sample set FR were determined by neutron activation analysis (NAA, Becquerel Laboratories, Canada), whereas for sample set WW low-level gamma-spectrometry was carried out (VKTA Rossendorf, Germany). The dose rates include the cosmic dose contribution which was calculated according to the present sampling depth (PRESCOTT \& HutTon, 1994). All values are shown with their 1 sigma-error.

Tab. 1: Dosisleistungswerte berechnet für die Quarz-Fraktion unter Berücksichtigung eines mittleren Wassergehaltes von $14 \pm 5$ Gew.-\%. RadionuklidKonzentrationen des Probensatzes „FR“ wurden mittels Neutronen-Aktivierungs-Analyse (NAA, Becquerel Laboratories, Canada) bestimmt, die des Probensatzes „WW“ mittels hochauflösender Gamma-Spektroskopie (VKTA Rossendorf). In der Dosisleistung ist der Anteil der kosmischen Dosisleistung berücksichtigt, der entsprechend der Beprobungstiefe berechnet wurde (PRESCOTT \& HUTTON 1994).

\begin{tabular}{|c|c|c|c|c|c|c|}
\hline Lab.-code & Sample & Depth $(\mathrm{m})$ & Dose rate $(\mathrm{Gy} / \mathrm{ka})$ & $\mathrm{U}(\mathrm{ppm})$ & Th $(\mathrm{ppm})$ & $\mathrm{K}(\%)$ \\
\hline C-L2019 & FR 1 & 5.33 & $2.62 \pm 0.19$ & $2.19 \pm 0.15$ & $10.53 \pm 0.34$ & $1.65 \pm 0.05$ \\
\hline C-L2020 & FR 2 & 5.07 & $2.67 \pm 0.20$ & $3.23 \pm 0.19$ & $9.61 \pm 0.31$ & $1.47 \pm 0.05$ \\
\hline C-L2022 & FR 4 & 4.45 & $2.56 \pm 0.19$ & $2.59 \pm 0.15$ & $9.99 \pm 0.32$ & $1.47 \pm 0.05$ \\
\hline C-L2024 & FR 6 & 3.83 & $2.57 \pm 0.19$ & $3.06 \pm 0.17$ & $9.37 \pm 0.30$ & $1.45 \pm 0.05$ \\
\hline C-L2028 & FR 10 & 2.60 & $2.36 \pm 0.18$ & $2.47 \pm 0.15$ & $8.38 \pm 0.27$ & $1.41 \pm 0.05$ \\
\hline C-L2029 & WW 1 & 6.37 & $2.62 \pm 0.20$ & $3.22 \pm 0.13$ & $11.00 \pm 0.40$ & $1.40 \pm 0.07$ \\
\hline C-L2030 & WW 2 & 6.16 & $2.32 \pm 0.17$ & $2.96 \pm 0.12$ & $10.30 \pm 0.30$ & $1.16 \pm 0.04$ \\
\hline C-L2033 & WW 5 & 5.66 & $2.55 \pm 0.19$ & $3.24 \pm 0.13$ & $10.40 \pm 0.40$ & $1.35 \pm 0.05$ \\
\hline C-L2035 & WW 7 & 5.00 & $2.60 \pm 0.19$ & $2.82 \pm 0.11$ & $10.40 \pm 0.40$ & $1.50 \pm 0.05$ \\
\hline
\end{tabular}

Tab. 2: Luminescence ages obtained for the fine sand quartz fraction using different single-aliquot regeneration dose protocols. The ages which are considered to be the most reliable are highlighted. ${ }^{1}$ The number of aliquots measured and used to calculate the average equivalent dose. ${ }^{2} R S D=$ relative standard deviation of the De-data set. ${ }^{3}$ Overdispersion of the De data set. ${ }^{4}$ Depending on the dispersion of the individual De-estimates the mean value of the equivalent doses is based on either the common or central age model (GALBRAITH et al. 1999). COM= common age model, CAM = central age model. ${ }^{5}$ All measurements were carried out on automated Risø TL/OSL readers (type TL-DA-12, -15, or -20, BØTTER-fENSEN et al. 2003) using small aliquots ( 300 grains per aliquot) and the following settings: Quartz, OSL: detection U340 filter (7.5 mm thickness), pre-heat $10 \mathrm{~s} @ 240^{\circ} \mathrm{C}$, cut-heat $160^{\circ} \mathrm{C} T L, 50 \mathrm{~s} @ 125^{\circ} \mathrm{C}$ blue stimulation, hotbleach after test dose OSL: $40 \mathrm{~s} @ 280^{\circ} \mathrm{C}$, Quartz, ITL: detection U340 filter (7.5 mm thickness), $500 \mathrm{~s} @ 310^{\circ} \mathrm{C}$ (hold $10 \mathrm{~s}$ @ $310^{\circ} \mathrm{C}$ before meas.). The De-errors include a $5 \%$ uncertainty for the beta source calibration.

Tab. 2: Ergebnisse der Lumineszenz-Datierungen für die Feinsand-Quarz-Fraktion auf Basis unterschiedlicher SingleAliquot-Regenerierungs-Protokolle. Wahrscheinlichste Alter sind hervorgehoben. ${ }^{1}$ Anzahl der gemessenen und zur Bestimmung der mittleren Äquivalenzdosis (De) herangezogenen Teilproben. ${ }^{2}$ RSD $=$ relative Standardabweichung des De-Datensatzes. ${ }^{3}$ Ausmaß der Streuung des De-Datensatzes. ${ }^{4}$ Mittelwerte der Äquivalenzdosis basieren in Abhängigkeit von der Streuung der Einzelwerte entweder auf dem "common" oder "central age model" (GALBRAITH et al. 1999). COM= common age model, CAM = central age model. ${ }^{5}$ Alle Messungen wurden auf automatisierten Risø TL/ OSL Messgeräten (type TL-DA-12, -15, oder-20, BøTTER-JENSEN et al. 2003) unter Verwendung kleiner Teilproben ( 300 Körner pro Teilprobe) und folgender Messkonfiguration durchgeführt: Quarz, OSL: Detektion U340 Filter (7,5 mm), Vorheizen $10 \mathrm{~s} @ 240^{\circ} \mathrm{C}, 160^{\circ} \mathrm{C}$ TL, $50 \mathrm{~s} @ 125^{\circ} \mathrm{C}$ blaue Stimulation, thermo-optisches Bleichen nach Test-Dosis OSL: $40 \mathrm{~s}$ @280 ${ }^{\circ} \mathrm{C}$, Quarz, ITL: Detektion U340 Filter (7,5 mm), $500 \mathrm{~s} @ 310^{\circ} \mathrm{C}$ (vor der Messung Probe $10 \mathrm{~s} @ 310^{\circ} \mathrm{C}$ gehalten). Die De-Fehler beinhalten eine 5\%ige Unsicherheit hinsichtlich der Beta-Quellen Kalibration.

\begin{tabular}{|c|c|c|c|c|c|c|c|c|}
\hline Lab.-code & Sample & $\mathrm{n}^{1}$ & ${\text { RSD }(\%)^{2}}^{2}$ & ${\text { OD }(\%)^{3}}^{3}$ & ${\text { Age } \text { model }^{4}}^{2}$ & De $(\mathrm{Gy})^{5}$ & OSL-age (ka) & ITL-age (ka) \\
\hline C-L2019 & FR 1 & 16 & 13.5 & 11.5 & CAM & $339 \pm 21$ & --- & $130 \pm 12$ \\
\hline C-L2020 & FR 2 & 17 & 10 & --- & COM & $315 \pm 18$ & --- & $118 \pm 11$ \\
\hline C-L2022 & FR 4 & 18 & 13.5 & --- & COM & $223 \pm 13$ & --- & $87.1 \pm 8.3$ \\
\hline \multirow{2}{*}{ C-L2024 } & \multirow{2}{*}{ FR 6 } & 17 & 13.7 & 10.8 & CAM & $203 \pm 12$ & --- & $79.0 \pm 7.4$ \\
\cline { 3 - 10 } & & 24 & 15.4 & 14.3 & CAM & $79.5 \pm 4.8$ & $30.9 \pm 2.9$ & --- \\
\hline C-L2028 & FR 10 & 24 & 21.5 & 17.2 & CAM & $59.9 \pm 3.8$ & $25.4 \pm 2.5$ & --- \\
\hline C-L2029 & WW 1 & 20 & 21.1 & 15.9 & CAM & $314 \pm 20$ & --- & $120 \pm 12$ \\
\hline C-L2030 & WW 2 & 11 & 23.3 & 18.0 & CAM & $231 \pm 19$ & --- & $99.4 \pm 11.0$ \\
\hline C-L2033 & WW 5 & 20 & 18.7 & 15.3 & CAM & $191 \pm 12$ & --- & $74.9 \pm 7.3$ \\
\hline C-L2035 & WW 7 & 19 & 15.1 & 13.8 & CAM & $188 \pm 11$ & --- & $72.3 \pm 6.8$ \\
\hline
\end{tabular}

ples are presented, which were taken from the site Inden-Altdorf (WW 2005/91, sample set WW) and from the loess sequence of the Elsbach valley (WW 2006/0086, sample set FR). All luminescence measurements were carried out on automated Risø TL/OSL readers (types TL-DA-12, -15, or 20) and followed single-aliquot regenerative-dose protocols (SAR). Per sample several sub-samples, or aliquots, were measured to obtain estimates of the amount of radiation dose accumulated within the crystal lattice of a mineral grain since it was shielded from sunlight (equivalent dose, $\mathrm{D}_{\mathrm{e}}$ ). To calculate the annual dose (dose rate, $\mathrm{D}_{0}$ ) derived from the decay of lithogenic radionuclides in the sediment, the concentration of uranium, thorium, and potassium in each sediment sample was determined by neutron activation analysis (sample set FR) or high-resolution low-level gamma spectrometry (sample set WW) (see Tab. 1). 


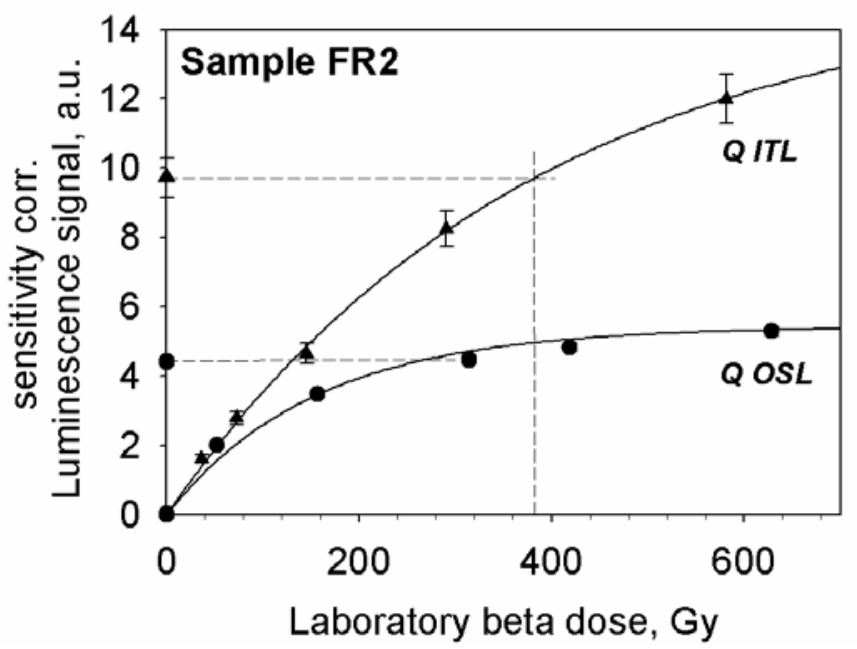

Fig. 6: Dose-response curve of sample FR2. At high doses the signal approaches a saturation level. The quartz OSL signal saturates at much lower doses than the ITL signal of the same sample (a.u. = arbitrary unit).

Abb. 6: Wachstumskurve der Probe FR2. Bei hohen Dosen zeigt sich eine Signalsättigung. Das Quarz-OSL-Signal erreicht dieses Sättigungsniveau deutlich früher als das ITL-Signal derselben Probe (a.u. = beliebige Einheit).

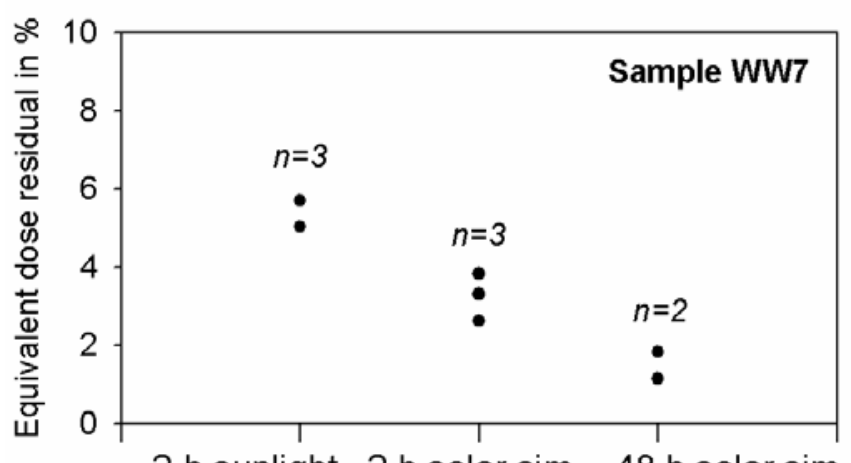

$2 \mathrm{~h}$ sunlight $2 \mathrm{~h}$ solar sim. $48 \mathrm{~h}$ solar $\operatorname{sim}$.

Fig. 7: Sub-samples of sample $W W 7$ were bleached either with sunlight or a solar simulator for 2 and $48 \mathrm{~h}$, respectively. After bleaching the residual ITL signal was measured and is plotted here in \% of the equivalent dose value. For the $2 \mathrm{~h}$-sunlight bleaching two aliquots yielded the same results.

Abb. 7: Teilproben der Probe WW 7 wurden sowohl mittels Sonnenlicht als auch im Solar-Simulator für 2 bzw. 48 h gebleicht. Nach der Bleichung wurde das Restsignal der ITL bestimmt und hier als prozentualer Anteil gegen die Äquivalenzdosis aufgetragen. Die 2-stündige Bleichung unter Sonnenlicht ergab für zwei Teilproben identische Ergebnisse.

All samples were prepared under subdued red light. The fine sand fraction was extracted by dry sieving and settling, and subsequently treated with $10 \%$-hydrochloric acid, $10 \%$-hydrogen peroxide and sodium oxalate to remove carbonates, organic material, and clay. Mineral separation was carried out using solutions of sodium polytungstate and HF etching to obtain a purified quartz fraction. For more details on the background of luminescence dating, the equipment, sample preparation, and the different measurement protocols the reader is referred to e.g. Preusser et al. (2008), BøtTER-JEnSEn et al. (2003) and Roberts (2008).

For samples FR 2, 6 and 10, the De of the quartz fraction was determined using a 'conventional' SAR protocol as described in Murray \& Wintle (2000) and Wintle \& Murray (2006). However, as illustrated in Fig. 6 for sam- ple FR 2, the quartz OSL dose response curve approaches saturation, thus the OSL protocol is not suitable for dating these samples. This observation is in accordance with the recommendations of BUYLAERT et al. (2008) who suggest application of the SAR-OSL procedure only for sand-sized quartz samples extracted from loess (in that case from the Chinese loess plateau) with burial doses below 120-150 Gy. In our study the signal saturation limits the practical age range for SAR-OSL to approximately 45-60 ka. As the time window beyond $80 \mathrm{ka}$ is of particular interest here, other luminescence protocols rather than quartz OSL had to be tested to provide reliable age information for the two study sites. We tested a variety of new measurement protocols focussing on the extension of the upper luminescence dating limit. In Table 2 (Section 4) dating results are presented which were obtained from OSL and isothermal thermoluminescence (ITL, CHOI et al. 2006; JAIN et al. 2007) of quartz. The quartz ITL signal has a much higher saturation level than the OSL signal (Fig. 6), allowing to date further back in time. Experiments on the optical resetting and the dose recovery yield promising results with respect to the applicability of ITL for the sediments investigated in this study. Residuals of 3-5\% ( 6-10 Gy) were measured after $2 \mathrm{~h}$ of sunlight bleaching and should allow dating of aeolian sediments with sufficient transport distance, i.e. bleaching time (Fig. 7).

For a dose recovery test (sample WW7), a laboratory dose of 50 Gy was administered after $48 \mathrm{~h}$ bleaching in the solar simulator. The ratio given/measured dose of $0.89 \pm 0.07$ indicates a tendency of overestimation of a burial dose by using the ITL approach. The residual after the $48 \mathrm{~h}$ bleaching was only $1.5 \%$ of the natural dose and thus is not the major cause for the overestimation. A further explanation is that sensitivity changes of the natural signal are not adequately monitored by the first test dose. BuylaERT et al. (2006) report on sensitivity changes that occur when the first heat treatment is applied to measure the natural signal. This change is not detected by the SAR procedure and led to an overestimation of ITL ages in their samples from the Chinese loess plateau (Buylaert et al. 2006). For our samples, the dose recovery ratio and residuals after bleaching are considered as acceptable, and the low spread in Devalues further argues for a general applicability of the applied ITL-protocol. However, a certain overestimation of our ITL ages cannot be ruled out.

\section{Results}

The element concentrations and calculated ratios determined for the section of the Elsbach valley (Figs. 8, 9) offer a subdivision into three geochemical units. From the top of the analytical sequence to the base of the rust spotted Ah horizon (first unit) a weak secondary carbonate precipitation can be assumed, visible in the $\mathrm{Ti} / \mathrm{Ca}$ and the $\mathrm{Sr} / \mathrm{Rb}$ ratio. With respect to the $\mathrm{Ti} / \mathrm{Ca}$ ratio a strong weathering degree can be verified for this unit. In addition, maximal values of the $\mathrm{K} / \mathrm{Rb}$ ratio, resulting from an increase of $\mathrm{K}$, indicate secondary clay enrichment.

The second unit comprises the stagnic AhE horizon, the bleached stagnic horizon and the weak humic Bt horizon, characterised by significantly increasing values of the 


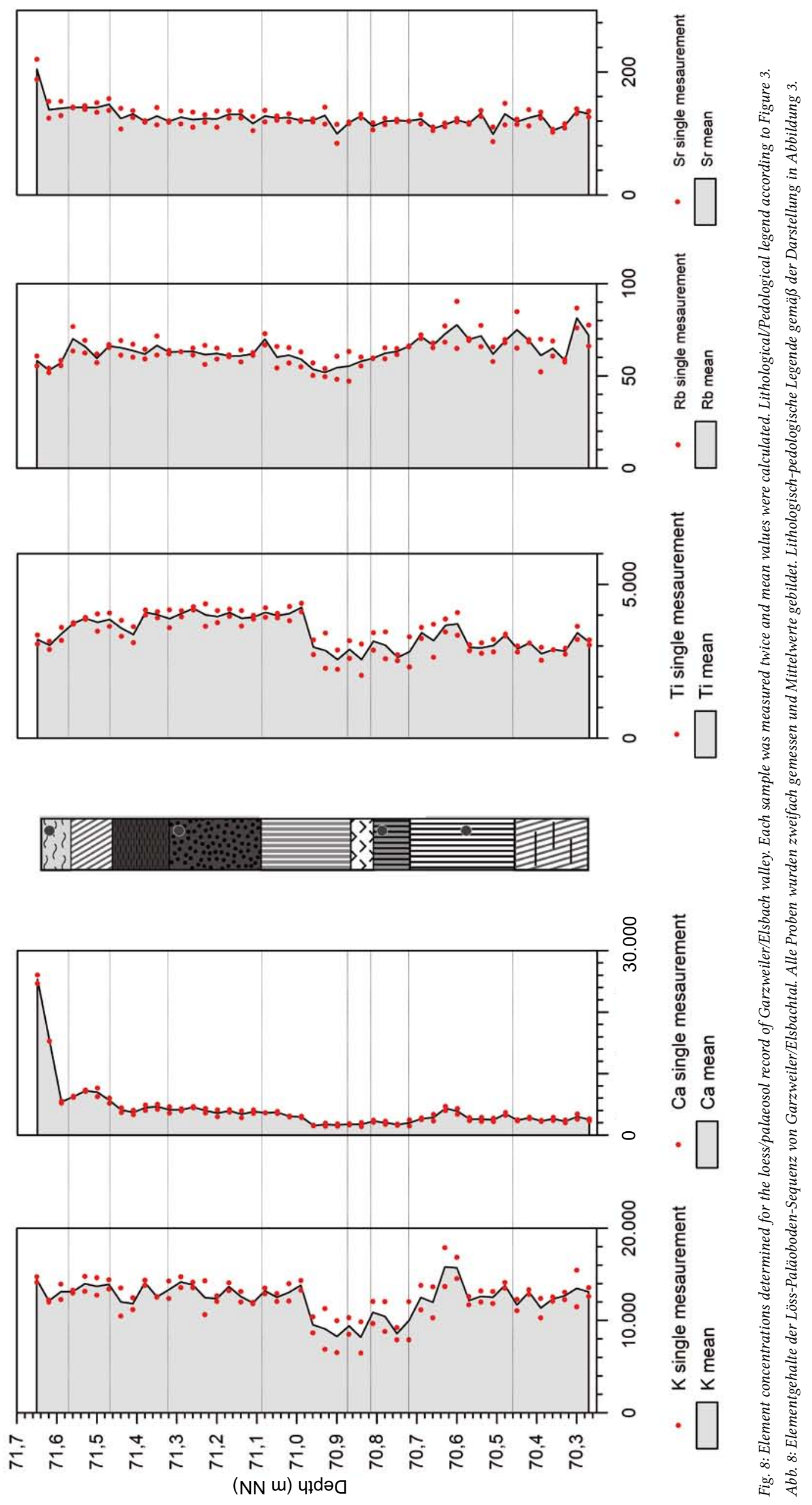



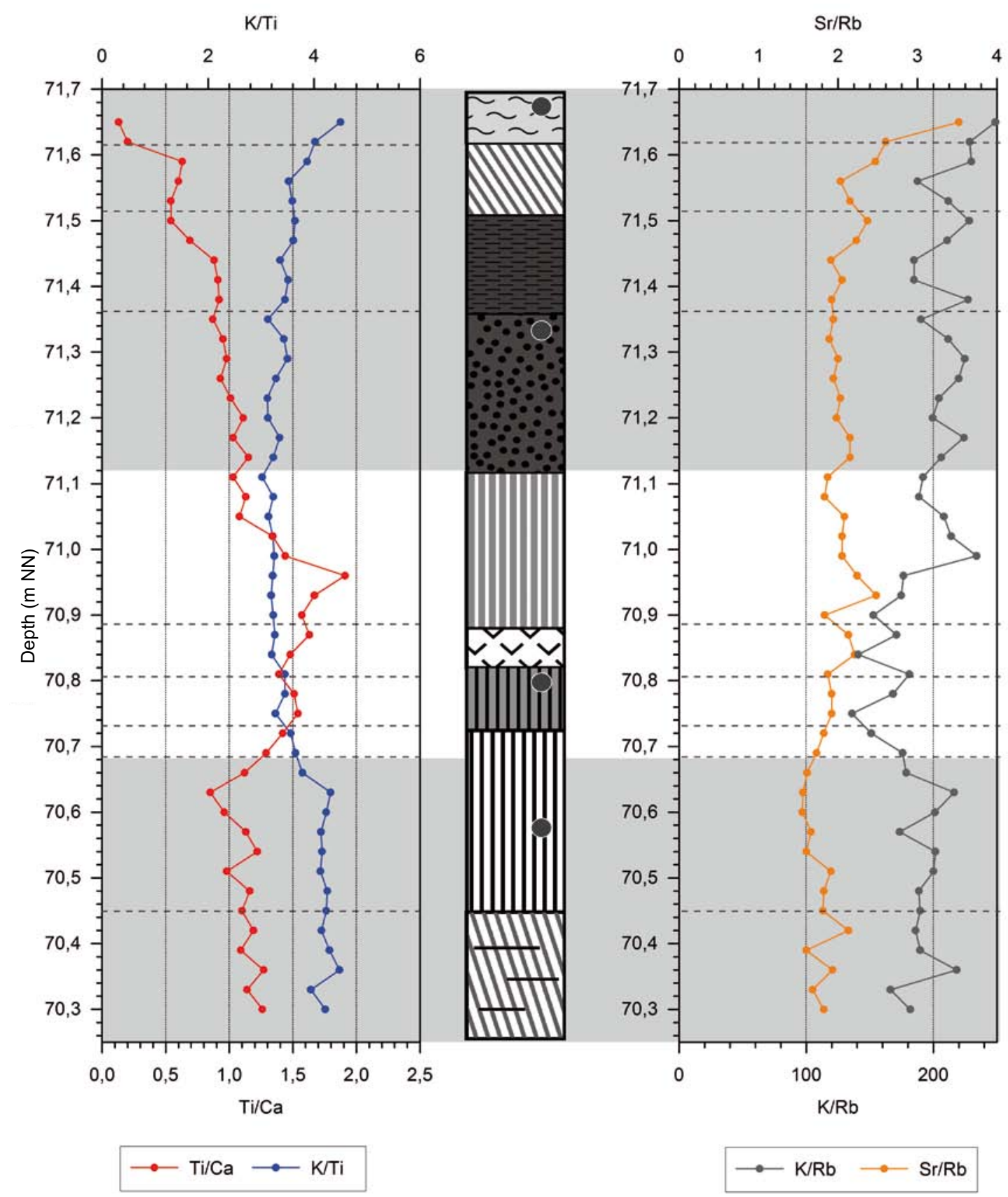

$30.9+1-2.9$

(OSL)

$87.1+/-8.3$

(ITL)

II

$118+/-11$

(ITL)

$130+/-12$

(ITL)

III

Fig. 9: Selected element ratios in the loess/palaeosol record of Garzweiler/Elsbach valley showing different soil formation processes including weathering degrees. Lithological/Pedological legend according to Figure 3. Units I-III are described in the text.

Abb. 9: Ausgewählte Elementverhältnisse aus der Löss/Paläoboden-Sequenz von Garzweiler/Elsbachtal, an denen sich bodenbildende Prozesse und Verwitterungsintensitäten ableiten lassen. Lithologisch-pedologische Legende gemäß der Darstellung in Abbildung 3. Die Einheiten I-III werden im Text erläutert.

$\mathrm{Ti} / \mathrm{Ca}$ ratio and a maximum peak within the stagnic AhE horizon. This implicates in situ weathering processes for Unit II. Clay dislocation towards the weak humic Bht-horizon and the top of unit III as based on field evidence is also indicated by the decreasing trend of the $\mathrm{K} / \mathrm{Rb}$ ratio.

The third unit consists of the well developed Btg horizon and the lamellic Bw horizon. Within this unit clay illuviation is reflected in the $\mathrm{K} / \mathrm{Ti}, \mathrm{K} / \mathrm{Rb}$ and $\mathrm{Sr} / \mathrm{Rb}$ ratios.

Luminescence dating (for labelling and position of the samples cp. Fig. 3) yielded quartz ITL ages of $130 \pm 12 \mathrm{ka}$ for the parent material of the Btg horizon (unit III, sample FR 1) and $118 \pm 11$ ka for the humic Bt horizon (unit II, sample FR 2), respectively.
The sediment superimposed by the rust spotted Ah horizon yielded an ITL-age of $87.1 \pm 8.3 \mathrm{ka}$ (unit I, sample FR 4). Sample FR 6 out of the reworked loess and soil material provided an OSL-age of $30.9 \pm 2.9 \mathrm{ka}$. In this sample, the ITL-age $(79.0 \pm 7.4)$ clearly overestimates the quartz OSL age (Tab. 2). Most likely, this can be explained by the reworked nature of the sediment. The short transport distance might have been insufficient to reset the harder to bleach ITL-signal, but was adequate to effectively bleach the quartz OSL signal. In addition, the possibility of sensitivity changes during ITL-measurements has to be taken into account, which may have led to overestimation of all ITL ages (cp. Section 3.2). The uppermost sample (FR 10) 

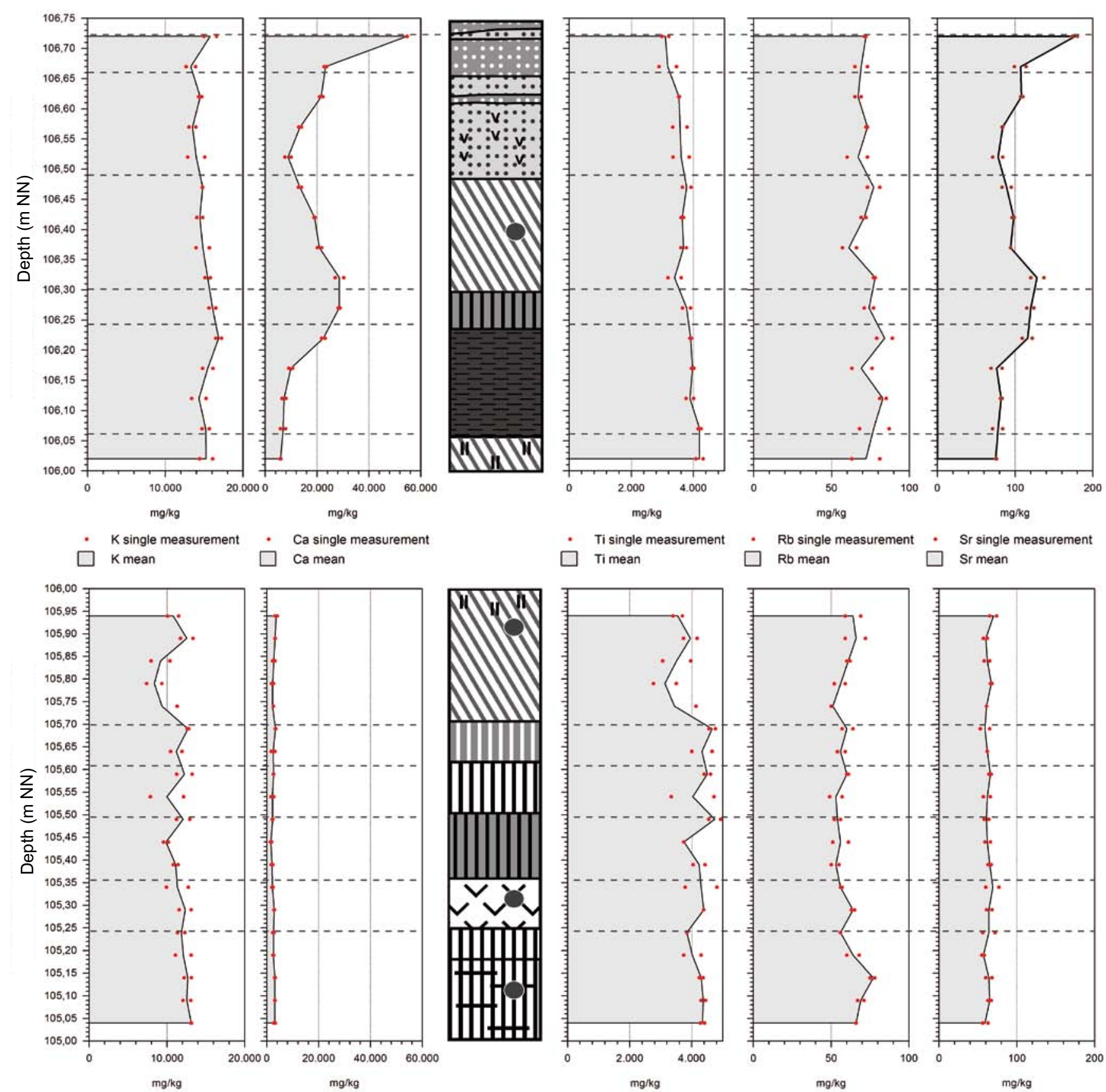

Fig. 10: Element concentrations determined for the loess/palaeosol record of Inden-Altdorf. Each sample was measured twice and mean values were calculated. Lithological/Pedological legend according to Figure 5.

Abb. 10: Elementgehalte der Löss-Paläoboden-Sequenz von Inden-Altdorf. Alle Proben wurden zweifach gemessen und Mittelwerte gebildet. Lithologischpedologische Legende gemäß der Darstellung in Abbildung 5.

out of reworked calcareous loess sediments yielded an OSL age of $25.4 \pm 2.5 \mathrm{ka}$.

For the Inden-Altdorf sequence, five geochemical units can be differentiated based on the element contents and the calculated ratios (Figs. 10, 11). The first unit comprises hydromorphically stained loess sediments, which are superimposed by a rust spotted Gelic Gleysol in the upper part of the analytical sequence. The second unit consists of the reworked loess and soil material, the weak humic Bt horizon and the upper part of the Ah horizon. The Ti/Ca ratio shows a minimum on top of the weak humic Bt horizon correlating with a maximum in the $\mathrm{Sr} / \mathrm{Rb}$ ratio. This alteration in the values is accompanied by an increasing propor- tion of the sand fraction (Fig. 12, top). Within the weak humic $\mathrm{Bt}$ horizon an enrichment of potassium is indicated by a slight increase in the $\mathrm{K} / \mathrm{Ti}$ and the $\mathrm{K} / \mathrm{Rb}$ ratios correlating with a decreasing proportion of the sand fraction and an increase of the fine fraction.

The third unit comprises the lower part of the Ah horizon, the reworked layer and the underlying stagnic AhE horizon and is characterised by comparable tendencies within the ratios as described for the first unit. In contrast the Ti/Ca values are significantly higher. The humic upper part of this unit shows increasing clay content (cp. Fig. 12), which is also reflected in potassium enrichment relative to titanium. 

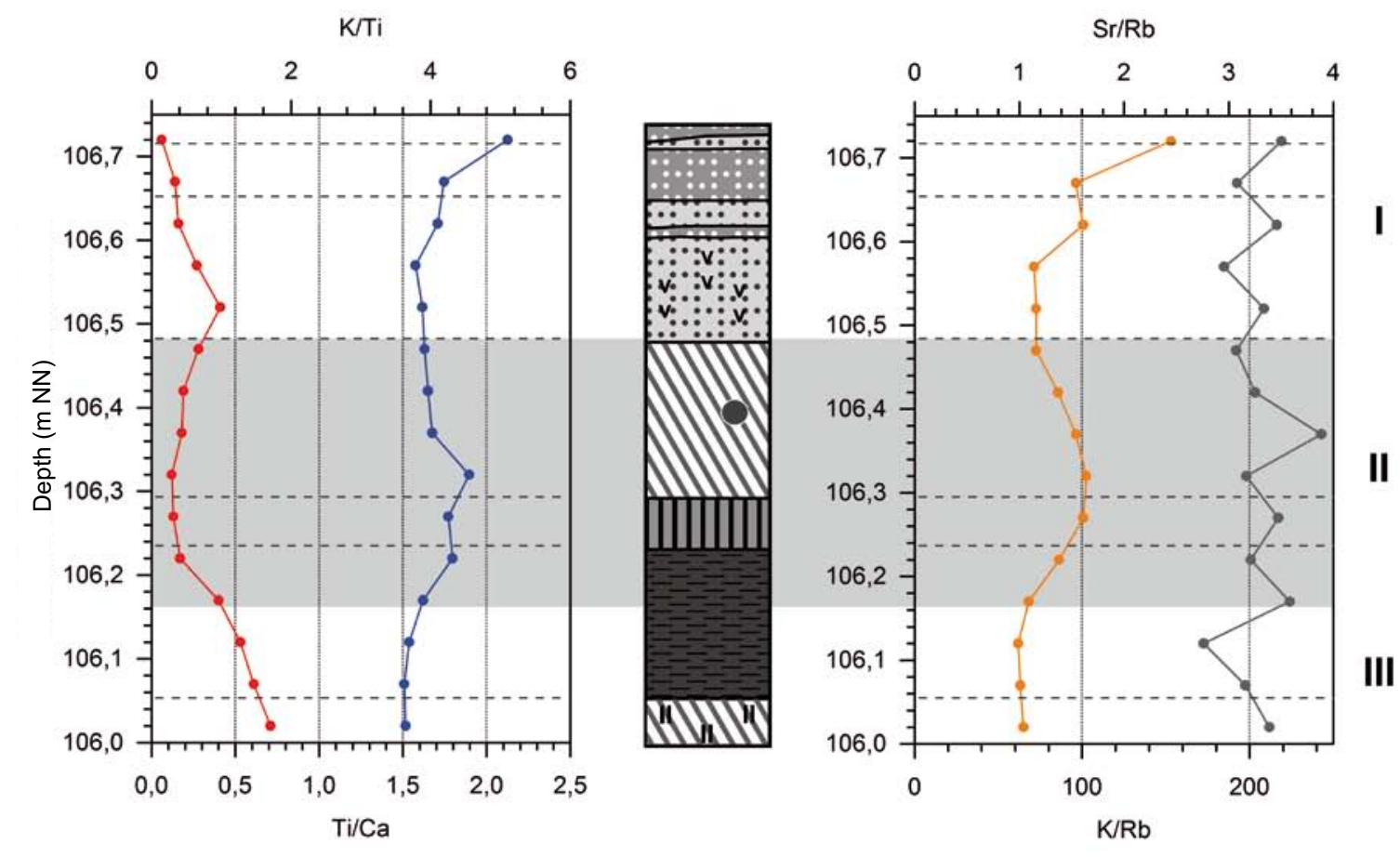

Age (ka)
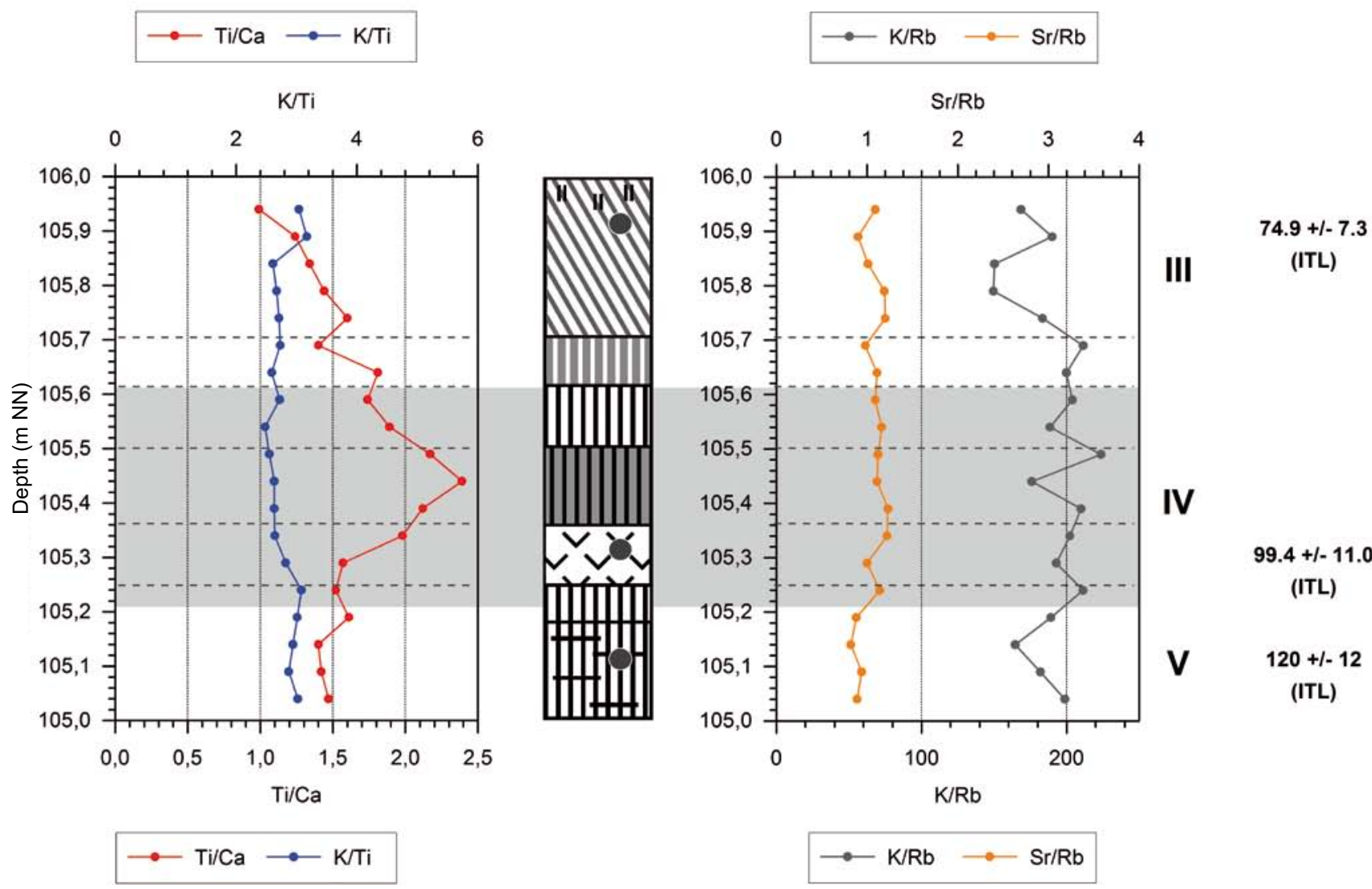

$72.3+/-6.3$

(ITL)

\section{I}

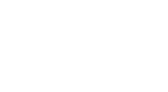

$+1-7.3$

TL)

(ITL)

$+1-12$

(1)

Fig. 11: Selected element ratios in the loess/palaeosol record of Inden-Altdorf showing different soil formation processes including weathering degrees. Lithological/pedological legend according to Figure 5. Units I-V are described in the text.

Abb. 11: Ausgewählte Elementverhältnisse aus der Löss/Paläoboden-Sequenz von Inden-Altdorf, an denen sich bodenbildende Prozesse und Verwitterungsintensitäten ableiten lassen. Lithologisch-pedologische Legende gemäß der Darstellung in Abbildung 5. Die Einheiten I-V werden im Text erläutert.

Within the fourth unit, containing the weak Bt, the humic Bt horizon, the bleached stagnic horizon and the uppermost part of the Btg horizon, a distinct maximum in the $\mathrm{Ti} / \mathrm{Ca}$ values is noticed. Simultaneously the potassium content slightly decreases in relation to the titanium content.
Including the low $\mathrm{K} / \mathrm{Rb}$ ratio this is associated with a reduced amount of clay. The lowermost unit (unit V) contains the lower part of the Btg and the lamellic Bt horizon. It is characterised by increasing clay contents. This increase is displayed in all selected ratios (cp. Fig. 11). 

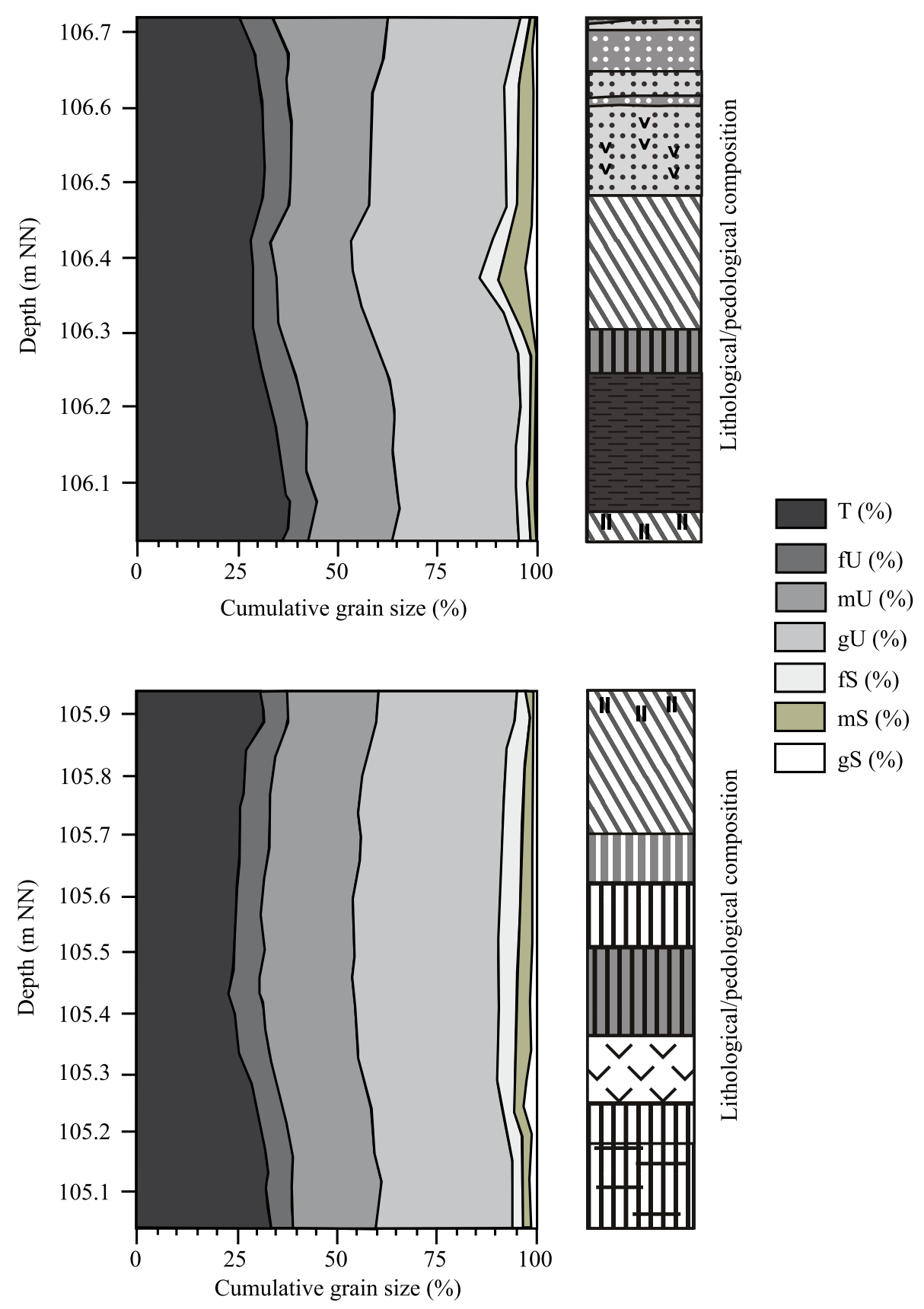

Fig. 12: Grain size distribution of the loess/ palaeosol record of Inden-Altdorf. Lithological/pedological legend according to Figure 5. (T: clay, fU: fine silt, $m U$ : medium silt, gU: coarse silt, fS: fine sand, $m S: m e-$ dium sand, $g S$ : coarse sand, according to AG Boden, 2005)

Abb. 12: Korngrößenverteilung in der Löss/ Paläoboden-Sequenz von Inden-Altdorf. Lithologisch-pedologische Legende gemäß der Darstellung in Abbildung 5. (Korngrößenklassen gemäß AG Boden 2005)

Luminescence dating (for labelling and position of the samples cp. Fig. 5) yielded an ITL-age of $120 \pm 12 \mathrm{ka}$ for the lowermost sample out of the lamellic Bt horizon (unit V, sample WW 1). Sample WW 2 obtained within the bleached stagnic horizon (unit 4) yielded an ITL-age of $99.4 \pm 11 \mathrm{ka}$. For sample WW 5 an ITL-age of $74.9 \pm 7.3$ ka below the Ah horizon and $72.3 \pm 6.8 \mathrm{ka}$ above the Ah-horizon (sample WW 7) was determined. As for the Elsbach valley section ITL-measurements applied to the samples from the IndenAltdorf section have to be viewed critically due to a possible overestimation of the true deposition age.

\section{Discussion}

In both investigated sequences, the lowermost Bt horizon, which presumably correlates with the last interglacial, is overlain by further weak Bt horizons of truncated Luvisols, stagnic and humic horizons, most likely correlating with the Lower Weichselian.
The age estimations obtained in the present study provide a chronostratigraphical frame for the period mentioned above, but the data set is small so far, and the ITL-ages are not totally reliable at this stage of the study. Additional measurements using the ITL-approach as well as measurements on the feldspar fraction have recently been conducted to evaluate the presented data set. Beside luminescence dating, for the first time, ratios derived from multi element analyses are included in the interpretation of loess/palaeosol records from the Lower Rhine area. The ratios show that the geochemical units (cp. Figs. 9, 11) partially exceed beyond horizon boundaries as derived from field observations and thus indicate polygenetic soil formation, which has to be further investigated by means of soil micromorphology.

The element ratios obtained for the lower unit of the Elsbach valley record show Bt features superimposed by secondary clay illuviation, which was also noticed in the field in terms of clay coatings. It could be hypothesised that 
(i) relocation of a well developed Bt horizon occurred followed by postsedimentary pedogenetic processes; (ii) relocation of pre-weathered soil sediment (showing no Bt features, e.g. Bw, Cw horizons) was followed again by postsedimentary pedogenetic processes leading to the formation of Bt features or (iii) input or relocation of "unweathered", calcareous and laminated sediments as parent material was superimposed by soil formation. Here, investigations on thin sections would be helpful to clarify the formation scenario.

The results obtained for the lower part of the IndenAltdorf record indicate secondary (postsedimentary) pedogenetic processes in terms of clay illuviation as well.

The overlying sequence in both records is characterized by a distinct maximum of the $\mathrm{Ti} / \mathrm{Ca}$ ratios (Unit II in the Elsbach valley record, Unit IV in the Inden-Altdorf record). In the Elsbach valley this peak is developed within an $\mathrm{AhE}$ horizon, in Inden-Altdorf within a weak humic Bt horizon. The element ratios, especially the $\mathrm{Ti} / \mathrm{Ca}$ ratio as well as the ITL data indicate an input of allochthonous (pre-weathered) soil sediments. Secondary pedogenetic processes such as clay enrichment are reflected in the K/Ti and the $\mathrm{K} / \mathrm{Rb}$ ratios, and are attended by decreasing clay contents in the overlying units. The observed unconformities on top of the lowermost Bt features support the assumption of allochthonous soil sediment relocation.

In contrast to Inden-Altdorf a weakly developed humic Bt horizon below the unconformity at $70.9 \mathrm{~m} \mathrm{(cp.} \mathrm{Fig.} \mathrm{3)} \mathrm{is}$ described for the Elsbach valley record superimposing the underlying Bt-features. The ITL age of $118 \pm 11 \mathrm{ka}$ (sample FR 2) indicates a Late Eemian or Early Weichselian depositional age. Within the Inden-Altdorf sequence the sediments of the bleached stagnic horizon, where archaeological findings were imbedded yielded an age of $99 \pm 11 \mathrm{ka}$, indicating a Lower Weichselian age.

The uppermost unit of the Elsbach valley section is characterised by the most intensive weathering within the whole sequence as displayed in the $\mathrm{Ti} / \mathrm{Ca}$ ratio. Especially the high values of the $\mathrm{K} / \mathrm{Rb}$ ratio imply the (re-) deposition of soil sediments (cp. section 3.2, section 4). The precipitation of secondary carbonate (leading to a masking of the Ti-derived weathering index) indicates leaching of carbonates from the hanging layers. For the parent material the ITL age of $87.1 \pm 8.3 \mathrm{ka}$ out of the rust spotted humic horizon is available, allowing a correlation with the Lower Weichselian. Distinct reworking processes are noticed in the uppermost part of the record as well as in the analytical sequence. The OSL age of $30.9 \pm 2.9 \mathrm{ka}$ indicates sediment accumulation during increased geomorphogenic activity towards the onset of MIS 2, in which older sediments and soils were relocated. The layer intercalated between the sandy reworked loess and soil sediments and the uppermost humic horizon most likely contains reworked soil sediments of the Middle Weichselian.

In the Inden-Altdorf section on top of the uppermost humic horizon, superimposed by a weak humic Bt horizon, the ITL age of $72.3 \pm 6.8 \mathrm{ka}$ within the reworked layer indicates a deposition of the parent material at the onset of MIS 4. Based on the $\mathrm{Ti} / \mathrm{Ca}$ and $\mathrm{Sr} / \mathrm{Rb}$ ratio, an increase in carbonate content can be assumed, which could be due to secondary precipitation from the hanging, calcareous loess sediments or reflects an input of weakly weathered mate- rial. Clay enrichment corresponding with the macroscopically indentified weak Bht horizon is reflected by the $\mathrm{K} / \mathrm{Ti}$ and the $\mathrm{K} / \mathrm{Rb}$ ratios, which increase in the uppermost part of the underlying humic horizon.

In summary multiple sediment re-deposition and polygenetic pedological processes have to be considered for both records displaying the complexity of the investigated sequences. This leads to difficulties in correlation with existing stratigraphical schemes in the Lower Rhine area.

Schirmer (at last 2010) describes the MIS 5 pedocomplex as Rocourt Solcomplex, consisting of four Bt horizons, three humic and three stagnic horizons on top of each Bt horizon. The pedocomplex was denominated after the well known type locality Rocourt in the northwest of Liège (Belgium) by Gullentops (1954).

However, focusing on the Eemian to Early Weichselian period, only few luminescence data are available for the Lower Rhine area. The published luminescence ages are mainly based on IRSL-dating of feldspars or on thermoluminescence (TL), measured with multiple aliquot protocols (e.g. ZöLlER et al. 1988; ZÖLLER 1989; JANOTTA 1991; Frechen et al. 1992; Henze 1998). A detailed discussion of different luminescence dating protocols for the investigated records is in preparation.

Based on field evidence the soil sediments on top of the uppermost humic horizon in Inden-Altdorf most likely correlate with the lower Keldach loess as described by SCHIRMER (e.g. 2002), which is also defined as Niedereschbach Zone in the Rhine-Main area (SEMmel 1968). In the record of the Elsbach valley the uppermost unconformity on top of the reworked soil sediments of the Middle Weichselian most likely corresponds with the so called Eben-unconformity with the Eben Zone sensu Schirmer (e.g. 2003) on top. Comparable distinct erosional phases dating to the early Upper Weichselian are described for example by SEMmEL (1989) and Meyer \& Rohdenburg (1982). A detailed correlation of the lower part of the sequences remains uncertain. The humic horizons most likely correlate with the Mosbacher Humuszonen of the Lower Weichselian sensu ScHöNHALS et al. (1964) which are correlated to the Pesch, Holz and Titz humus zones (Schirmer, e.g. 2002). These humic zones partially show basal $\mathrm{B}(\mathrm{t})$ horizons. The uppermost humic layers in the records under study possibly correlates with the (reworked) "Titz" humus zone, in Garzweiler followed by the rust spotted "Holz" humus zone with the "Holz" soil underneath. The stratigraphical relevance of the weak humic Bt horizon on top of the uppermost humic horizon in Inden as well as the weak humic Bt horizon on top of the distinct Bt features in Garzweiler needs further clarification.

Following Schirmer's description and interpretation the Rocourt Solcomplex is developed as relatively thin pedocomplex in flat relief positions whereas soil divergence occurs towards the slope toe and in small depressions (ScHIRMER 2010: 37). In the latter positions the most complete stratigraphical records can be observed.

So called syn-solcomplex erosion results in a truncation of Luvisols, which is associated with the onset of cold periods (breviglacials sensu ScHIRMER 1999) leaving erosional remnants of the pedocomplex behind. Within these cold periods dust accumulation occurred resulting in a separation of the fossil soils by thin loess sediments. It is assumed 
that small depressions as well as foot slope positions remain more protected from erosion than other geomorphological positions (SCHIRMER 2010: 34). The results presented here do not support this observation: The occurrence of soil sediments in slope positions as demonstrated for the records under study indicate that spreading of sequences does not generally reflect the climate conditions during soil formation but possibly represent erosional events. Both records are located in some distance to the (palaeo-) watershed position, hence were affected by active slope formation processes in transition periods from stable to unstable morphodynamic conditions. The soil horizons possibly do not represent relics of in situ formation, but originate from soil sediments as indicated by discordant bedding. Especially in foot slope positions and depressions, which are characterised by enhanced water percolation, pedogenesis should lead to an even stronger alteration of accumulated sediments resulting in a greater variety of diagnostic soil characteristics than observed.

The interplay of morphogenetic processes according to the relief position with the polygenetic superimposition of truncated palaeosols stresses the need for a comprehensive geomorphological/pedological analysis of comparable sequences for a sound chronostratigraphical and palaeoclimatical interpretation (cp. Frechen, Terhorst \& RÄHLE 2007; STEPHAN 2000).

\section{Conclusion}

The geomorphological and palaeoclimatological interpretation of pedocomplexes of the Eemian and Lower Weichselian is a complex task not only leading to problems in chronostratigraphical correlation of archaeological records incorporated in these layers. The multi-element screening is a promising tool to characterise sediments and soils within loess/palaeosol records of the Lower Rhine area.

The applicability of luminescence techniques to create a more reliable chronostratigraphical frame for the time period under investigation still needs further research, especially for loess sediments with equivalent doses in or close to the OSL-saturation level. The applied ITL-approach does not argue against the observed litho- and pedostratigraphy. However, possible sensitivity changes not detected and corrected might pose a problem for the interpretation of obtained ages. Possibly, the application of the single aliquot regeneration and added dose procedure (SARA) within the ITL-approach as suggested by BUYLAERT et al. (2006) can help to investigate the reliability of the ages presented here.

For the archaeological find layer at the site of Inden-Altdorf it is concluded that it did not occur in autochthonous position but rather was incorporated in soil sediments of Lower Weichselian age. This conclusion contrasts the interpretation of the supervising archaeologists (cp. THISSEN 2007; PAwlik \& Thissen 2011). Despite the archaeological evidence, in the publication by PAwLIK $\approx$ THISSEN (2011:71) the find layer and the upper part of the interglacial soil are described as "reworked" by M. Kehl based on field evidence and micromorphological studies. In addition preliminary IRSL-data produced by M. Frechen yield Lower Weichselian ages. These details are not being further discussed by
PAwlik \& Thissen (2011) but clearly support the conclusions drawn here.

The results show that within the Lower Weichselian of the Lower Rhine area multiple sediment deposition and/ or relocation events are documented, delivering the parent material for polygenetic soil formation.

Main objectives of future studies should be the accurate differentiation of primary sediments, in situ soils and relocated soil sediments prior to stratigraphical correlation, using a wide methodological spectrum. In addition, the morphological position and the palaeorelief in the surrounding of investigated loess/palaeosol sequences require more attention in future studies.

\section{Acknowledgments}

Funding of the "Stiftung Archäologie im Rheinischen Braunkohlerevier" in context of the project "Paläolithikum im Indetal" (Proposal number 173) is appreciated. Furthermore we thank the two reviewers for helpful comments to improve the manuscript and Dr. Johanna Lomax, Vienna, for linguistic improvements.

\section{References}

AG Boden (2005): Bodenkundliche Kartieranleitung (5. Auflage). - 438 S.; Hannover (BGR).

AhorNER, L. (1962): Untersuchungen zur quartären Bruchtektonik der Niederrheinischen Bucht. - Eiszeitalter und Gegenwart, 13: 24-105.

Boenigk, W. \& Frechen, M. (1995): Lumineszenz-Datierungen an kolluvialen Sedimenten des Elsbachtales. - Bonner Jahrbücher, 195: 299-312.

Bokhorst, M.P., BeEts, C.J., Marković, S.B., Gerasimenko, N.P., Matvishina, Z.N. \& Frechen, M. (2009): Pedo-chemical climate proxies in Late Pleistocene Serbian-Ukrainian loess sequences. Quaternary International, 198: 113-123.

Bøtter-Jensen, L., McKeever, S.W.S. \& Wintle, A.G. (2003): Optically Stimulated Luminescence Dosimetry. - 404 S.; Amsterdam (Elsevier).

BRUNNACKER, K. (1967): Grundzüge einer Löß- und Bodenstratigraphie am Niederrhein. - Eiszeitalter und Gegenwart, 18: 142-151.

Buggle, B., Glaser, B., Zöller, L., Hambach, U., Marković, S., Glaser, I. \& Gerasimenko, N. (2008): Geochemical characterization and origin of Southeastern and eastern European loesses (Serbia, Romania, Ukraine). - Quaternary Science Reviews, 27: 1058-1075.

Buggle, B., Glaser, B., Hambach, U., Gerasimenko, N. \& Marković, S. (2010): An evaluation of geochemical weathering indices in loesspaleosol studies. - Quaternary International, 240: 12-21.

Buylaert, J. P., Murray, A. S., Huot, S., Vriend, M. G. A., VandenBerghe, D., De Corte, F. \& van den Haute, P. (2006): A comparison of quartz OSL and isothermal TL measurements on Chinese loess. Radiation Protection Dosimetry, 119: 474-478.

Buylaert, J.P., Murray, A.S., Vandenberghe, D., Vriend, M., De Corte, F. \& VAN DEN HAUTE, P. (2008): Optical dating of Chinese loess using sand-sized quartz: Establishing a time frame for Late Pleistocene climate changes in the western part of the Chinese Loess Plateau. Quaternary Geochronology, 3: 99-113.

Choi, J.H., Murray, A.S., Cheong, C.S., Hong, D.G. \& Chang, H.W. (2006): Estimation of equivalent dose using quartz isothermal TL and the SAR procedure. - Quaternary Geochronology, 1: 101-108.

Derbyshire, E., Kemp, R \& Meng, X (1995): Variations in loess and palaeosols properties as indicators of palaeoclimatic gradients across the Loess Plateau of North China. - Quaternary Science Reviews, 14: 681-697.

Fischer, P. (2010): Zur mittel- und jungquartären Relief- und Bodenentwicklung der nordwestlichen Kölner Bucht - Detailuntersuchungen der lössbedeckten Mittelterrassenlandschaft. - Dissertation Universität zu Köln, 253 S.; Köln. http://kups.ub.uni-koeln.de/volltexte/2010/3030/.

Frechen, M., Boenigk, W. $\mho$ Weidenfeller, M. (1995): Chronostratigraphie des „Eiszeitlichen Lößprofils“ in Koblenz-Metternich. - Mainzer geowissenschaftliche Mitteilungen, 24: 155-180. 
Frechen, M., Brückner, H. \& RAdtKe, U. (1992): A comparison of different TL-techniques on loess samples from Rheindahlen (F.R.G.). Quaternary Science Reviews, 11: 109-113.

Frechen, M., Terhorst, B. \& RÄhle, W. (2007): The Upper Pleistocene loess/palaeosol sequence from Schatthausen in North Baden-Württemberg. - E\&G Quaternary Science Journal, 56 (3): 212-227.

Galbraith, R.F., Roberts, R.G., Laslett, G.M., Yoshida, H. \& Olley, J.M. (1999): Optical dating of single and multiple grains of quartz from Jinmium Rock Shelter, Northern Australia: Part I, Experimental design and statistical models. - Archaeometry, 41: 339-364.

GALlET, S., JAHN, B. \& ToRII, M. (1996): Geochemical characterization of the Luochuan loess-palaeosol sequence, China, and its paleoclimatic implications. - Chemical Geology, 133: 157-172.

Gullentops, F. (1954): Contribution à la chronologie du Pleistocène et des formes du relief en Belgique. - Mémoires de l' Institut géologique de l' Université de Louvain, 18: 125-252.

Henze, N. (1998): Kennzeichnung des Oberwürmlösses in der Niederrheinischen Bucht. - Kölner Forum für Geologie und Paläontologie, 1: 212 S.; Geologisches Institut der Universität zu Köln.

HoodA, P. [ed.] (2010): Trace Elements in Soils. - 616 S.; Chippenham, Wiley.

Jain, M., Murray, A.S. \& Bøtter-Jensen, L. (2007): Dose response, thermal stability and optical bleaching of the $310^{\circ} \mathrm{C}$ isothermal TL signal in quartz. - Radiation Measurements, 42: 1285-1293.

JAnotTA, A. (1991): Thermolumineszenzdatierungen als chronometrischer Beitrag zur stratigraphischen Beschreibung von Lößprofilen. - Düsseldorfer Geographische Schriften, 30: 116 S.

Kabata-Pendias, A. (2010): Trace Elements in Soils and Plants. - 4. ed., 520 S.; Boca Raton (CRC Press).

Kels, H. (2007): Bau und Bilanzierung der Lössdecke am westlichen Niederrhein. - Dissertation Universität Düsseldorf: 206 S.; Düsseldorf. http://docserv.uni-duesseldorf.de/servlets/DocumentServlet?id=3628.

Kels, H., Kehl, M., Lehmkuhl, F., Tegtmeier, U. \& Thissen, J. (2009) Naturwissenschaftliche Untersuchungen zum mittelpaläolithischen Camp von Inden-Altdorf. - Archäologie im Rheinland, 2008: 36-39.

Koster, E. A. (2005): Recent Advances in Luminescence Dating of Late Pleistocene (Cold-Climate) Aeolian Sand and Loess Deposits in Western Europe. - Permafrost and Periglacial Processes, 16: 131-143.

LÖHR, H. \& BRUnNAcker, K. (1974): Metternicher und Eltviller TuffHorizont im WürmLöß am Mittel und Niederrhein. - Notizblatt des hessischen Landesamtes für Bodenforschung., 102: 168190.

LuI, T. (1985): Loess and the Environment. - 251 S.; Beijing (China Ocean Press).

LuI, T. (1991): Loess, Environment and Global Change. - 288 S. Beijing (Beijing Science Press).

Meyer, B. \& Rohdenburg, H. (1982): Paläoböden der südniedersächsischen Lößgebiete. - Geolgisches Jahrbuch, F 14: 298-309.

Murray, A.S., Wintle, A.G. (2000): Luminescence dating of quartz using an improved single-aliquot regenerative-dose protocol. - Radiation Measurements, 32: 57-73.

PAAs, W. (1961): Rezente und fossile Böden auf niederrheinischen Terrassen und deren Deckschichten. - Eiszeitalter und Gegenwart, 12: $165-230$.

PAAs, W. (1968a): Gliederung und Altersstellung der Lösse am Niederrhein. - Fortschritte in der Geologie von Rheinland und Westfalen, 16: $185-196$.

PAAs, W. (1968b): Stratigraphische Gliederung des Niederrheinischen Lösses und seiner fossilen Böden. - Decheniana, 121 (1/2): 9-38.

Pawlik, A. F. \& Thissen, J. (2011): The 'Palaeolithic Prospection in the Inde Valley`Project. - Quaternary Science Journal (Eiszeitalter und Gegenwart), 60: 66-77.

PÉcsi, M. \& RICHTER, G. (1996): Löss - Herkunft, Gliederung, Landschaften. - Zeitschrift für Geomorphologie. N. F., Suppl.- Bd., 98: 391 S.; Berlin, Stuttgart.

Prescott, J.R. \& Hutton, J.T. (1994): Cosmic ray contributions to dose rates for luminescence and ESR dating: large depth and long time variations. - Radiation Measurements, 23: 497-500.

Preusser, F., Degering, D., Fuchs, M., Hilgers, A., Kadereit, A., Klasen, N., KrbetscheK, M., Richter, D. \& Spencer, J. (2008): Luminescence dating: Basics, methods and applications. - E\&G Quaternary Science Journal, 57 (1/2): 95-149.

Remy, H. (1960): Der Löß am unteren Mittel- und Niederrhein. - Eiszeitalter und Gegenwart,11: 107-120.

Roberts, H. M. (2008): The development and application of luminescence dating to loess deposits: a perspective on the past, present, future. Boreas, 37: 483-507.
Rohdenburg, H. \& Meyer, B. (1966): Zur Feinstratigraphie und Paläopedologie des Jungpleistozäns nach Untersuchungen an südniedersächsischen und nordhessischen Lössprofilen. - Mitteilungen der Deutschen Bodenkundlichen Gesellschaft, 5: 1-137.

Schirmer, W. (1999): Kaltzeiten und Warmzeiten im Löß. - In: BeckerHaumann, R. \& Frechen, M. [eds.]: Terrestrische Quartärgeologie. - 81-100; Köln (Logabook).

Schirmer, W. (2000a): Rhein loess, ice cores and deep-sea cores during MIS 2-5. - Zeitschrift der Deutschen Geologischen Gesellschaft, 151: $309-332$.

Schirmer, W. (2000b): Eine Klimakurve des Oberpleistozäns aus dem rheinischen Löss. - Eiszeitalter und Gegenwart, 50: 25-49.

Schirmer, W. (2002): Compendium of the Rhein loess sequence. - In IKINGER, A. \& SCHIRMER, W. [eds.]: Loess units and solcomplexes in the Niederrhein and Maas area. - Terra Nostra, 2002 (1): 8-23.

Schirmer, W. (2003): Die Eben-Zone im Oberwürmlöss zwischen Maas und Rhein. - In: ScHIRMER, W. [ed.]: Landschaftsgeschichte im Europäischen Rheinland. GeoArchaeoRhein, 4: 351-416.

Schirmer, W. (2010): Interglacial complex and solcomplex. - Central European Journal of Geosciences, 2: 32-40.

Schirmer, W. \& Kels, H. (2002): Browncoal opencast mine Garzweiler. In: IKINGER, A. \& Schirmer, W. [eds.]: Loess units and solcomplexes in the Niederrhein and Maas area. - Terra Nostra, 2002 (1): 57-65, 102-104.

Schönhals, E., Rohdenburg, H. ¿ Semmel, A. (1964): Ergebnisse neuerer Untersuchungen zur Würmlöß-Gliederung in Hessen. - Eiszeitalter und Gegenwart, 15: 199-206.

Schulz, W. (2007): Die Kolluvien der westlichen Kölner Bucht: Gliederung, Entstehungszeit und geomorphologische Bedeutung. - Dissertation Universität zu Köln: 218 S.; Köln. http://kups.ub.uni-koeln.de/1965/.

SEmmel, A. (1968): Studien über den Verlauf jungpleistozäner Formung in Hessen. - Frankfurter Geographische Hefte, 45: 133 S.

Semmel, A. (1989): The importance of loess in the interpretation of geomorphological processes and for dating in the federal Republic of Germany. - Catena, Suppl., 15: 179-188.

Singhvi, A. K., Bluszcz, A., Bateman, M. D. \& Someshwar Rao, M. (2001): Luminescence dating of loess-palaeosol sequences and coversands: methodological aspects and palaeoclimatic implications. - Earth-Science Reviews, 54: 193-211.

Smalley, I. J., Jefferson, I. F., Dijkstra, T. A. \& Derbyshire, E. (2001): Some major events in the development of the scientific study of loess. - Earth Science Reviews, 54: 5-18.

SMYKATZ-Kloss, B. (2003): Die Lößvorkommen des Pleiser Hügellandes bei Bonn und von Neustadt/Wied sowie der Picardie: Mineralogischgeochemische und geomorphologische Charakterisierung, Verwitterungs-Beeinflussung und Herkunft der Lösse. - Dissertation Universität Bonn: 343 S.; Bonn. http://hss.ulb.uni-bonn.de:90/2003/0308/0308.htm.

Smykatz-Kloss, W., Smykatz-Kloss, B., Naguib, N. \& Zöller, L. (2004) The reconstruction of paleoclimatological changes from mineralogical and geochemical compositions of loess and alluvial loess profiles. - In: Smykatz-Kloss, W. \& Felix-Henningsen, P. (eds): Palaeoecology of Quaternary Drylands. Lecture Notes in Earth Sciences, 102: 101-118.

Stephan, S. (2000): Bt-Horizonte als Interglazial-Zeiger in den humiden Mittelbreiten: Bildung, Mikromorphologie, Kriterien. - Eiszeitalter und Gegenwart, 50: 95-106.

Thissen, J. (2006): Mit dem Bagger in die Altsteinzeit - „Prospektion Paläolithikum im Indetal“ - Archäologie im Rheinland, 2005: 28-30.

Thissen, J. (2007): Ein Camp des Micoquien im Indetal bei Altdorf. Archäologie im Rheinland, 2006: 42-45.

Uthmeier, T. (2006): Am Ufer lauert der Tod - Jagdplätze des Neandertalers in der niederrheinischen Bucht: Ergebnisse einer archäologischen Prospektion der Abbaukanten im rheinischen Braunkohlerevier. - In: Uelsberg, G. (ed.): Roots/Wurzeln der Menschheit: 269-288.

WintLE, A.G. \& MuRRAY, A.S. (2006): A review of quartz optically stimulated luminescence characteristics and their relevance in single-aliquot regeneration dating protocols. - Radiation Measurements, 41: 369-391.

ZöLLER, L. (1989): Geomorphologische und geologische Interpretation von Thermolumineszenz-Daten. - Bayreuther geowissenschaftliche Arbeiten, 14: 103-112.

Zöller, L., Stremme, H. E. Æ Wagner, G. A. (1988): ThermolumineszenzDatierung an Löß-Paläoboden-Sequenzen von Nieder-, Mittel- und Oberrhein. - Chemical Geology, 73: 39-62.

ZÖller, L. \& SEMmel, A. (2001): 175 years of loess research in Germany - long records and "unconformities". - Earth-Sciences Reviews, 54: $19-28$. 